\title{
Disruptions' Function: A Defense of (Some) Form Objections under the Federal Rules of Civil Procedure
}

\author{
Amir Shachmurove* \\ "Objection, evasion, joyous distrust, and love of irony—signs of health."
}

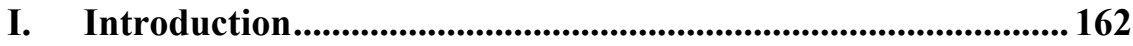

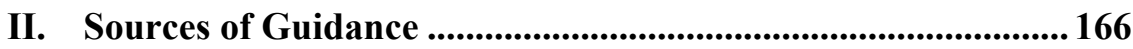

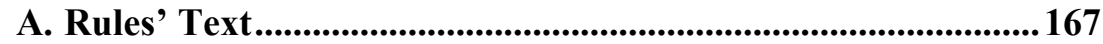

1. Spirit of Discovery (Rules 1 and 26) ................................170

2. Special Class of Depositions (Rule 27)................................175

3. Deposition Procedures (Rules 30 and 31) ........................177

4. General Restrictions on a Deposition's Use (Rule 32) ..... 181

5. Deposition Objections: Manner (Rules 30) and Waiver

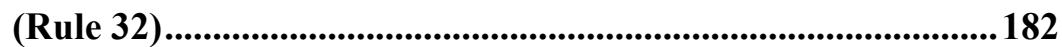

B. Case Law: Simple Form Objections versus Precise Form

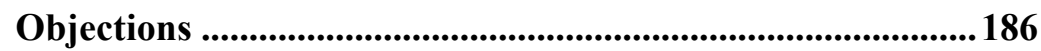

III. Sources of Confusion ............................................................... 190

\footnotetext{
* Amir Shachmurove is a law clerk at the United States District Court for the Middle District of Louisiana and formerly clerked at the United States District Court for the Southern District of California and two United States Bankruptcy Courts. He can always be reached at ashachmurove@post.harvard.edu. This article is dedicated to the Honorable William V. Gallo, the fairest of judges and most generous of men, and his permanent staff: Ms. Megan C. Nesvig, his ebullient career clerk, and Mr. Matthew T. Brown, his nononsense deputy. The author could have written no word here (or anywhere for that matter) but for six friends-Joshua H. Cooperman, Michael Glick, Delen Heisman, Danny Nguyen, William Yu, and Ji Zhang - and Ms. Lindsey L. Dunn. As always, every mistake made and every opinion expressed is the author's own.

1 Friedrich Nietzsche, Beyond Good And Evil 69 (Marion Faber ed. \& trans., Oxford University Press 2008).
} 
A. Elastic Definition of "Form"

B. Other Hurdles: Absent Standards and Discretionary Terms 192

IV. A Coherent Interpretation of Rules 30 and 32 ......................... 194

A. Relevant Principles ................................................................194

B. Rules' Intimations .......................................................................... 197

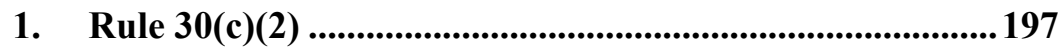

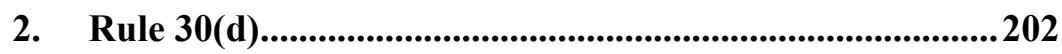

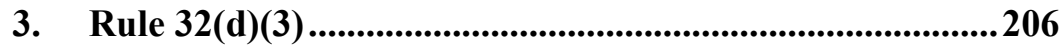

C. Broader Context.......................................................................................208

V. Conclusion ........................................................................................ 211

\section{INTRODUCTION}

Objections; misstates testimony. She said she doesn't recall. Go ahead and answer if you have a different answer.

I - again, with a verbal —- I need a verbal answer.

I don't recall ....

Objection; asked and answered. Go ahead and answer the question if you know.

I don't recall, huh-uh... .

Objection; vague and ambiguous as to 'harm.'

Can you clarify harm, what harm means?

Do you understand - you know the English language quite well I take it.

Originally seen as a sharp instrument for truth's discovery, ${ }^{2}$ a heady image still educed, ${ }^{3}$ the oral deposition authorized by Federal Rule of Civil

\footnotetext{
2 William W. Schwarzer, The Federal Rules, the Adversary Process, and Discovery Reform, 50 U. PITT. L. REV. 703, 703 (1989) (summarizing this vision).

3 See, e.g., Life Plans, Inc. v. Sec. Life of Denver Ins. Co., 800 F.3d 343, 358 (7th Cir. 2015) ("The purpose of discovery is to refine the case and to prepare it for trial based on a full understanding of the relevant facts."); King v. Asset Appraisal Servs., Inc., No.
} 
Procedure $30,{ }^{4}$ observers would later conclude, had lost much of its effectiveness by the time the Rules reached middle-age. ${ }^{5}$ Repeated objections, often lengthy and suggestive, appeared to have rendered too many depositions long and unproductive, and exchanges akin to the ones excerpted throughout this article were judged to be far too common. True, many depositions smoothly took place. ${ }^{6}$ Even so, pesky objections of dubious need and value, their exclamation inconsistent with the collegiality implicitly favored by the Rules' discovery provisions, ${ }^{7}$ seemingly mucked up the functioning of the Rules' pretrial-discovery system with maddening regularity. ${ }^{8}$ Wholly unexpectedly, discovery had transformed litigation into an "ordeal,", efficiency and justice, the fixed

8:05CV27, 2006 U.S. Dist. LEXIS 67224, at*3, 2006 WL 6475586 (D. Neb. Sept. 14, 2006) ("Discovery rules are to be 'broadly and liberally construed' in order to serve the purpose of discovery, which is to provide the parties with information essential to the proper litigation of all relevant facts, to eliminate surprise, and to promote settlement.") (citing, among others, Rolscreen Co. v. Pella Prods. of St. Louis, Inc., 145 F.R.D. 92, 94 (S.D. Iowa 1992))).

4 Throughout this article, this article uses the word "Rule" or "Rules" to refer to one or more Federal Rules of Civil Procedure.

5 By one account, during their first thirty years, the Rules worked satisfactorily. JOHN H. Beisner, U.S. Chambers Inst. For Legal Reform, The Centre Cannot Hold: The NeEd For EfFective Reform Of THE U.S. Civil Discovery Process 9 (2010).

6 See Linda S. Mullenix, The Pervasive Myth of Pervasive Discovery Abuse: The Sequel, 39 B.C. L. REV. 683, 684-85 (1998) (discussing discovery generally).

7 The Sedona Conference, The Sedona Conference Cooperation Proclamation 1 (2008) ("Lawyers have twin duties of loyalty: While they are retained to be zealous advocates for their clients, they bear a professional obligation to conduct discovery in a diligent and candid manner."); see also, e.g., Bonilla v. Trebol Motors Corp., No. 92-1795 (JP), 1997 U.S. Dist. LEXIS 4370, at*7-8, 1997 WL 178844, at *3 (D.P.R. Mar. 27, 1997) (quoting Schwarzer, supra note 2, at 714); cf. Griffin B. Bell, Chilton D. Varner \& Hugh Q. Gottschalk, Automatic Disclosure in Discovery - The Rush to Reform, 27 GA. L. REV. 1, 12-14 (1992) (discussing the various reasons why self-regulation of discovery has become increasingly problematic in recent years, including lawyers' conception of themselves as their clients' zealous advocates). Over the last twenty years, many model codes have deleted such once common references to zealous advocacy. E. Phelps Gay, Professionalism in Depositions: The Sound of Silence, 54 FED'N DEF. \& CORP. Couns. Q. 193, 195 n.7 (2011).

8 See, e.g., Paul W. Grimm \& David S. Yellin, A Pragmatic Approach to Discovery Reform: How Small Changes Can Make a Big Difference in Civil Discovery, 64 S.C. L. REV. 495, 499 (2013); John H. Beisner, Discovering a Better Way: The Need for Effective Civil Litigation Reform, 60 DuKE. L.J. 547, 549 (2010); John S. Beckerman, Confronting Civil Discovery's Fatal Flaws, 84 MinN. L. REV. 505, 509 (2000).

9 Schwarzer, supra note 2, at 716; see also, e.g., Dahl v. City of Huntington Beach, 84 F.3d 363, 364 (9th Cir. 1996) ("If there is a hell to which disputatious, uncivil, vituperative lawyers go, let it be one in which the damned are eternally locked in discovery disputes with other lawyers of equally repugnant attribute " (citing Krueger v. Pelican Prod. Corp., No. CIV-87-2385-A (W.D. Okla. Feb. 24, 1989))); Francis E. McGovern \& E. Allan Lind, The Discovery Survey, 51 LAw \& CONTEMP. ProBs. 41, 41 (1988) ("Formal discovery under the Federal Rules of Civil Procedure is one of the most abused and obfuscated aspects of our litigation practice."). 
stars in the Rules' cosmography, ${ }^{10}$ often unrealizable due to such interruptions' prevalence. ${ }^{11}$ So the story went; so it still goes. ${ }^{12}$

In response to this perception, ${ }^{13}$ even as one command remained mostly unchanged, ${ }^{14}$ Rules 26,30 , and 32 would be repeatedly redrafted. Sanctified by history, in 1938 and ever afterward, some objections were deemed too valuable for waiver to ever be appropriate. ${ }^{15}$ But those "relat[ing] to the manner of taking the deposition, the form of a question or answer, the oath or affirmation, a party's conduct, or other matters that might have been corrected at that time" were made so if "not timely made during the deposition," "16 an unadulterated codification of the so-called "contemporaneous objection rule."17 Today, however, objections must

10 See FED. R. CIV. P. 1; cf. Surowitz v. Hilton Hotels Corp., 383 U.S. 363, 373, 86 S. Ct. 845, 851, 15 L. Ed. 2d 807, 814 (1966) ("The basic purpose of the Federal Rules is to administer justice through fair trials . . . . These rules were designed in large part to get away from some of the old procedural booby traps which common-law pleaders could set to prevent unsophisticated litigants from ever having their day in court.").

11 See, e.g., Elliot v. Mission Trust Servs., LLC, No. 14 C 9625, 2015 U.S. Dist. LEXIS 45412, at $* 22$ n.13, 2015 WL 1567901, at *7 n.13 (N.D. Ill. Apr. 7, 2015) (collecting sources); see also sources cited in n.9.

12 See, e.g., Sec. Nat'l Bank v. Jones Day, 800 F.3d 936, 942 (8th Cir. 2015); Grimm \& Yellin, supra note 8; at 499; Beisner, supra note 8, at 549-50.

13 Some question the degree to which discovery abuse exists. See, e.g., Amelia F. Burroughs, Mythed It Again: The Myth of Discovery Abuse and Federal Rule of Civil Procedure 26(b)(1), 133 McGeorge L. Rev. 75, 93 (2001); Linda S. Mullenix, Discovery in Disarray: The Pervasive Myth of Pervasive Discovery Abuse and the Consequences for Unfounded Rulemaking, 46 STAN. L. REV. 1393, 1395-97, 1410-32, 1440-43 (1994); Sempier v. Johnson \& Higgins, 45 F.3d 724, 734 (3d Cir. 1995) ("The vast majority of federal discovery tools operate, when used properly, almost entirely without the court's involvement."). Attorneys' views of the discovery process in state courts, often governed by similarly worded rules, have also varied. Susan Keilitz, Roger Hanson \& Richard Semiatin, Attorneys' Views of Civil Discovery, JudgeS' J., Spring 1993, at 2, 34-35.

14 E. Stewart Moritz, The Lawyer Doth Protest Too Much, Methinks: Reconsidering the Contemporaneous Objection Requirement in Depositions, 72 U. CIN. L. REV. 1353, 1355, 1373-74 (2004).

15 See FeD. R. CIV. P. 32(d)(3)(A) (classifying only those objections relating to a defect that "might have been corrected at" the deposition's time as subject to waiver); Deno v. Blackman, No. 10 Civ. 8550 (KBF), 2011 U.S. Dist. LEXIS 137247, at *3, 2011 WL 5980174 , at $* 1$ (S.D.N.Y. Nov. 30, 2011) (citing language, as encapsulated in an earlier version of Rule 32).

16 FED. R. Civ. P. 32(d)(3)(B); Smith v. Stephens, No. 2:10-CV-13763, 2012 U.S. Dist. LEXIS 35631, at*20, 2012 WL 899347, at*6 (E.D. Mich. Mar. 16, 2012).

17 Moritz, supra note 14, at 1374. Colloquially, the contemporaneous objection rule holds that objections not made when grounds originally arise at trial may not be later raised on appeal. See FED. R. CRIM. P. 51(b); United States v. David, 83 F.3d 638, 644-45 (4th Cir. 1996) ("[O]ne of the fundamental purposes of the contemporaneous objection rule is to protect judicial resources, in particular by ensuring that the trial courts will have an opportunity to avoid errors that might otherwise necessitate time-consuming retrial."); $c f$. Craig Lee Murphy, Trial Objections from Beginning to End: The Handbook for Civil and Criminal Trials, 29 PEPP. L. REV. 243 (2002) (summarizing some of the most common trial 
also be "stated concisely in a nonargumentative and nonsuggestive manner" and may not include an instruction to the deponent not to answer if unnecessary "to preserve a privilege, to enforce a limitation ordered by the court, or to present a motion under Rule 30(d)(3)." 18 While the contemporaneous objection rule had been borrowed from another era, this requirement was newer, crafted so as to address concerns previously deemed unpersuasive. ${ }^{19}$ In once more attempting to mend this supposedly broken system, the most recent amendments to the Rules have left much untouched, and crucial questions unanswered. ${ }^{20}$

With only these express provisions and apparent ills as touchstones, a growing cavalcade of courts and scholars have wrangled over the proper content of an objection to a question's form. Many have insisted that the Rules, expressly and implicitly, condone the use of such phrases as "objection to form" or "objection, form" and nothing more. To them, such simple form objections, the phrase used in this article, are alone suitable. Others have demurred. Because the Rules clearly encourage and arguably impel that a proper objection divulge its precise ground, this coterie has asseverated that a simple form objection will never suffice. Instead, precise form objections, this piece's contrasting term, must always be used, an objection's foundation-"asked and answered," "ambiguous," "argumentative," "compound," and more-immediately published and inscribed into an unadorned record. At present, as courts doggedly quibble and districts inconsistently codify, ${ }^{21}$ precedent evinces a loud discord over whether a simple or a precise form objection best fits with the Rules' text and structure. ${ }^{22}$

objections). Like Professor Moritz, this article adopts the trial term for the rule though it deals solely with depositions. Moritz, supra note 14, at 1354 n.8.

18 FeD. R. Civ. P. 30(c)(2); Paige v. Consumer Programs, Inc., 248 F.R.D. 272, 276 (C.D. Cal. 2008).

19 See Stephen N. Subrin, Fishing Expeditions Allowed: The Historical Background of the 1938 Federal Discovery Rules, 39 B.C. L. REv. 691, 707-08, 717 (1998) [hereinafter Subrin, Fishing].

20 On December 1, 2015, a number of proposed amendments to Rules 1, 26, 34, among others, became effective. For a summary, see Daniel M. Braude \& Marianna Codispoti, Will Changes to Federal Rules Reduce Scope of Discovery?, LAw360, Dec. 11, 2015. Due to these amendments, some of the cases cited herein cite to these provisions, as numbered before December 1, 2015, though the language itself did not necessarily change. Thus, while this article cites to the Rules as newly amended, some of the cases will technically cite to the pre-winter of 2015 variants. As with other stylistic or structural changes effected since 1938 , only where the operative language was substantively changed, i.e. Rule $34(b)(2)(C)$, will it be so noted.

21 See infra Part II.B.

22 This article, then, does not concern itself with the kind of deposition misconduct punished in such cases as Paramount Commc'ns Inc. v. QVC Network, Inc., 637 A.2d 34 (Del. 1994), and, Hall v. Clifton Precision, 150 F.R.D. 525 (E.D. Pa. 1993). See also, e.g., Castillo v. St. Paul Fire \& Marine Ins. Co., 938 F.2d 776, 779-80 (7th Cir. 1991); Unique 
Delving into their language, specific context, and overall design before and after December 1, 2015, as required by prevailing principles of rule construction, ${ }^{23}$ this article takes a side, explicating why the Rules compel the use of precise form objections over their plainer kin. As a prelude, Part II summarizes the relevant Rules and the conflicting case law. Part III thereupon discusses the problems posed by uncertain denotations and the Rules' abstruse terminology and contradictory history. These preliminaries completed, Part IV proposes a rigorous defense for the use of precise form objections and an attack on the preference for simple form objections exhibited by too many. So as to cement this analysis' viability, Part IV first gives a short rundown of the law's most basic interpretive canons. Often overlooked, these controlling precepts must be consulted in an effort to divine the propriety of a particular form objection, for they dictate how the meaning of the Rules entire must be gleaned. Once these tenets are employed, as Part IV proceeds to show, precise form objections have three clinching virtues: unlike simple form objections, they (1) conform to the plain language of Rule 30(c)(2), (2) comport with the text and rationale of Rule 30(d), and (3) are more likely to attain Rule 32(d)(3)'s utilitarian ends. Further buttressing this normative conclusion, Part IV concludes by demonstrating that only these objections accord with the oral deposition's purpose and discovery's spirit. Proposed with caution, a resolution to a bubbling dispute lies herein, one that may ensure more modern depositions measure up to Rule 30's lofty ambitions,${ }^{24}$ rooted deep and not yet gone. ${ }^{25}$

\section{SOURCES OF GUIDANCE}

Okay. I'm going to note for the record that counsel's objections

Concepts, Inc. v. Brown, 115 F.R.D. 292, 293-94 (S.D.N.Y. 1987); Stengel v. Kawasaki Heavy Indus., 116 F.R.D. 263, 267-68 (N.D. Tex. 1987); Gay, supra note 7. The concerns raised in these cases and their progeny will matter, but as Part IV will explain, the reaction to toxic advocacy has failed to distinguish between the value of precise form objections and the use of discovery in a manner that results in "undue burden" and "unnecessary expense," Sandra F. Gavin, Playing by the Rules: Strategies for Defending Depositions, 1999 L. Rev. Mich. St. U. Det. C. L. 645, 656 n.1 (1999) (emphasis added). Simply put, in the drive to banish all unnecessary obstruction, subtleties have been ignored, and no balance struck, as the Rules rightly read compel. See infra Part IV.

23 See infra Part IV.A; see also Amir Shachmurove, Purchasing Claims and Changing Votes: Establishing “Cause” under Rule 3018(a), 89 AM. BANKR. L.J. 513, 528-34 (2015) (outlining these tenets).

24 John S. Beckerman, supra note 8, at 514.

$25 C f$. FED. R. CIV. P. 30 advisory committee's note to 2015 amendment ("Rule 30 is amended in parallel with Rules 31 and 33 to reflect the recognition of proportionality in Rule 26(b)(1).”). 
are coaching, which means that he's basically telling you what

he wants you to say when I ask a question.

They're completely not coaching. You're badgering the

witness....

Objection; vague and ambiguous as to 'harm.'

Can you clarify harm, what harm means? .. .

Objection; asked and answered.

Yeah, I already answered the question.

\section{A. Rules' Text}

Prior to September $16,1938,{ }^{26}$ a party's right to depose another rarely existed in federal court. ${ }^{27}$ A Progressive Era law had recognized it, ${ }^{28}$ but it subsisted in a most cabined form and never for the purposes of pretrial discovery. ${ }^{29}$ Influenced by equity's looser currents, the first advisory

26 The Court adopted the original Rules on December 20, 1937. The Rules were transmitted to Congress by the Attorney General of the United States on January 3, 1938, and became effective on September 16, 1938. Whether in regards to a rule's text or an advisory committee's note, any date used throughout this article is the relevant rule's effective one.

27 James A. Pike \& John W. Willis, The New Federal Deposition-Discovery Procedure: I, 38 COLUM. L. REV. 1179, 1183 (1938).

28 See Hanks Dental Ass'n v. Int'1 Tooth Crown Co., 194 U.S. 303, 305-08, 24 S. Ct. 700, 701-03, 48 L. Ed. 989, 989-90 (1904) (summarizing the relevant federal law); William SteWART Simkins, A FedERAl EQUiTy SuIT 512-15, 522-23 (1911) (describing early deposition strictures).

29 E.g., United States v. Bitter Root Dev. Co., 200 U.S. 451, 477-79, 26 S. Ct. 318, 326-27, 50 L. Ed. 550 (1908); accord S. Pac. R.R. Co. v. United States, 200 U.S. 341, 351, 26 S. Ct. 296, 298, 50 L. Ed. 507 (1906) ("It is enough that discovery was sought, that discovery is not obtainable in an action at law, but only in a suit in equity."); see also Sinclair Refining Co. v. Jenkins Petroleum Process Co., 289 U.S. 689, 696, 53 S. Ct. 736, 738, 77 L. Ed. 1449, 1455 (1933) (distinguishing Bitter Root Dev. Co., 200 U.S. at 472, on the basis that "[t]he complainant in that suit did not seek a discovery in aid of an action at law for the recovery of damages," as "[t]he suit was for general relief as well as for discovery, the prayer for discovery being merely incidental"); $c f$. Dan Downy \& Lori Massey, Discoverectomy II: The End of "Gotcha" Litigation, 13 REV. LITIG. 183, 191 n.43 (1993-94) (noting that the original purpose of depositions was to perpetrate testimony). Even William Blackstone criticized "[t]he want of a complete discovery by the oath of the parties." 3 William Blackstone, Commentaries, *381-82; see also Christopher $\mathrm{H}$. Foreman, Depositions and Discovery - Digest of Maryland Decisions, 18 MD. L. REv. 1, 1 (1958) ("One of the few criticisms Sir William Blackstone allowed himself to level at the common law was its lack of any effective means of discovery."). 
committee $^{30}$ extirpated these wizened controls. ${ }^{31}$ The Rules thereby created a "most liberal deposition procedure," separating "the right to take statements" from "the right to use them in court" and allowing for " $t]$ he utmost freedom . . . in taking depositions" and "the widest possible opportunity for knowledge by both the parties of all the facts before the trial." 32 Old limitations were forsaken, and an aged protestation-_"fishing expedition"33 — was divested of its former potency. ${ }^{34}$ Until $1983,{ }^{35}$ so long as the deposition questions related to the subject-matter of an action, the

30 Unless otherwise noted, any reference to "advisory committee" is to the Advisory Committee on Rules of Civil Procedure, and "standing committee" to the Committee on Rules of Practice and Procedure of the Judicial Conference of the United States.

31 Stephen N. Subrin, How Equity Conquered Common Law: The Federal Rules of Civil Procedure in Historical Perspective, 135 U. PA. L. REV. 909, 922 (1987) [hereinafter Subrin, Equity's Conquest]; see also, e.g., Subrin, Fishing, supra note 19, at 715; David L. Shapiro, Federal Rule 16: A Look at the Theory and Practice of Rulemaking, 137 U. PA. L. REV. 1969, 1975 (1989); cf. Isgrigg v. Schooley, 25 N.E. 151, 153 (Ind. 1890) ("[W]hen the law stops short of securing ... ['the rights of the parties'], equity continues the remedy until complete justice is done."). The differences in federal litigation between the late nineteenth and early twentieth centuries and today cannot be understated. See Crum v. Alabama (In re Emp't Discrimination Litig.), 213 F.R.D. 592, 599 (M.D. Ala. 2003).

32 Pike \& Willis, supra note 27, at 1187 (emphasis in original); see also Schlagenhauf v. Holder, 379 U.S. 104, 114-15, 85 S. Ct. 234, 241, 13 L. Ed. 2d 152, 161 (1964) (“"[T]he deposition-discovery rules are to be accorded a broad and liberal treatment' . . to effectuate their purpose that "civil trials in the federal courts no longer need be carried on in the dark.", (citations omitted) (quoting Hickman v. Taylor, 329 U.S. 495, 501, 507, 67 S. Ct. 385, 389, 392, 91 L. Ed. 451, 457, 460 (1947))); Beisner, supra note 8, at 556 \& n.38 (relying on William W. Schwarzer, Slaying the Monsters of Cost and Delay: Would Disclosure be More Effective Than Discovery?, 74 JUdiCATURE 178, 178 (1991)).

33 See, e.g., Carter v. Good, 10 N.Y.S. 647, 647-48 (N.Y. Gen. Term 1890) (noting that "[t]he rule with regard to the examination of a party before trial is one of discretion" and bars any "procedure in the nature of a fishing expedition . . . a forbidden performance"); In re Davis, 16 P. 790, 792 (Kan. 1888) ("The privilege of taking depositions should not and cannot be employed to fish from a witness facts that are irrelevant or incompetent to the issues in the case to be tried."); $c f$. In re Merkle, 19 P. 401, 402 (Kan. 1888) (finding a particular deposition to be "a justifiable fishing expedition," this determination "depend[ent] upon several contingencies that are not within the control of those seeking to take the [relevant] deposition").

34 Lavarett v. Cont'1 Briar Pipe Co., 25 F. Supp. 80, 82 (E.D.N.Y. 1938); see also Elizabeth G. Thornburg, Just Say "No Fishing": The Lure of Metaphor, 40 U. MicH. J.L. REFORM 1, 24 (2006) ("Most of the earliest post-Rule cases embraced broad discovery and rejected the 'fishing' objection." (citation omitted)).

35 In that year, the tide in favor of liberal discovery receded. See, e.g., FED. R. CIV. P. 26 advisory committee's note to 1983 amendment ("Given our adversary tradition and the current discovery rules, it is not surprising that there are many opportunities, if not incentives, for attorneys to engage in discovery that, although authorized by the broad, permissive terms of the rules, nevertheless results in delay."); Brian Morris, Note, The 2015 Proposals to the Federal Rules of Civil Procedure: Preparing for the Future of Discovery, 41 N. Ky. L. REV. 133, 133 (2014) ("For years, the various Judicial Rules Committees have received complaints about the abundant costs, burdens, and delays of litigating in the federal court system." (citations omitted)). 
Rules raised no bar to an oral deposition's administration. ${ }^{36}$ In their proponents' assessment, only by means of such relative openhandedness would discovery's principal aims - issues' narrowing and surprises' elimination-be realizable. ${ }^{37}$

In time, courts came to view the view Rules 30, 31, 33, 34, and 36 as fearsome implements. "[T]he wide latitude accorded to the inquiry," which may presently relate to any relevant claim or defense, to facts both ultimate and evidentiary and not exclusively within an adverse entity's knowledge or control, and is unfettered by the pesky doctrine of admissibility, partly explained this early impression. ${ }^{38}$ The fact that the Rules place no "initial burden on parties to justify their deposition and discovery requests" certainly helped. ${ }^{39}$ Even after December 1, 2015, this liberality, albeit tempered, has been retained. ${ }^{40}$

Yet, for all their studious attention, the drafters omitted one topic from the Rules' first iteration. With great care, they set forth a "detailed protocol"41 regarding a deposition's proper procedure. However, these same authors and many of their successors remained "silent about how or what type of objections could be made, when a defending attorney could instruct the witness not to answer, and the consequences if one side

36 See, e.g., Oppenheimer Fund, Inc. v. Sanders, 437 U.S. 340, 351, 98 S. Ct. 2380 , 2389, 57 L. Ed. 2d 253, 265 (1978); Glick v. McKesson \& Robbins, Inc., 10 F.R.D. 477, 479 (W.D. Mo. 1950). In 2000, "subject matter" was replaced with "claim or defense." FED. R. CIV. P. 26(b)(1) advisory committee's note to 2000 amendment; see also infra note 55.

37 See, e.g., McHugh v. Olympia Entm't, Inc., 37 F. App'x 730, 735 (6th Cir. 2002) ("Rule 26 must be read in light of its dual purposes of narrowing the issues and eliminating surprise.”); Barnes v. Dist. of Columbia., 270 F.R.D. 21, 24 (D.D.C. 2010) (“This type of request "can be most useful in narrowing and sharpening the issues, which is a major purpose of discovery." ' (quoting FED. R. CIV. P. 33(b) advisory committee's note to 1970 amendment)); Erica Gorga \& Michael Halberstam, Litigation Discovery and Corporate Governance: The Missing Story about the "Genius of American Corporate Law", 63 EMORY L.J. 1383, 1410-11 (2014) (summarizing discovery's original purposes).

38 FED. R. CIV. P. 26(b)(1); Official Comm. of Unsecured Creditors of Hechinger Inv. Co. of Del., Inc. v. Friedman (In re Subpoena Issued to Dennis Friedman), 350 F.3d 65, 70 (2d Cir. 2003).

39 In re Subpoena Issued to Dennis Friedman, 350 F.3d at 70.

40 Advisory Comm. on Civil Rules, Report to Comm. On Rules of Practice \& PROCEDURE 23 (May 2, 2014) ("Restoring the proportionality calculation to Rule 26(b)(1) does not change the existing responsibilities of the court and the parties to consider proportionality .... Nor is the change intended to permit the opposing party to refuse discovery simply by making a boilerplate objection that it is not proportional."), cited in FED. R. CIV. P. 26 advisory committee's note to 2015 amendment. Despite the change, it is crucial to note that this language had been part of Rule 26 for more than twenty years. $I d$.

41 GMAC Bank v. HTFC Corp., 248 F.R.D. 182, 184 (E.D. Pa. 2008) (saying so only as to Rule 30 ). 
delayed or impeded the examination." 42 Though much would be added in 1993 and in the ensuing two decades, the Rules would continue to touch upon the requisite conduct of parties, counsel, and deponents in no more than a handful of stray sentences. ${ }^{43}$

\section{Spirit of Discovery (Rules 1 and 26)}

The Rules' first substantive paragraph defines their scope and purpose. Per Rule 1, "the[] [R]ules govern the procedure in all civil actions and proceedings in the United States district courts, except as stated in Rule 81." 44 Rule 1's second independent clause promulgates the prescript intended to guide every rule's construction and application: "[The Rules] should be construed, administered, and employed by the court and the parties to secure the just, speedy, and inexpensive determination of every action and proceeding." 45 While the triad of "just, speedy, and inexpensive" date to 1937, two pertinent additions were made thereafter. First, in 1993, the advisory committee put in "and administered" with the "purpose" of clarifying the judge's role: "[T]o recognize the affirmative duty of the court to exercise the authority conferred by the $[R]$ ules to ensure that civil litigation is resolved not only fairly, but also without undue cost or delay." reminded attorneys, they too "share this responsibility with the judge to whom the case is assigned," 47 and "[e]ffective advocacy is consistent with - and indeed depends upon - cooperative and proportional use of procedure." ${ }^{48}$ Second, as of December 1, 2015, "employed" has extended

42 A. Darby Dickerson, The Law and Ethics of Civil Depositions, 57 MD. L. REV. 273, 279-80 (1998).

43 See infra Part II.A.5.

44 FeD. R. Civ. P. 1; United States v. Perez, 752 F.3d 398, 404 (4th Cir. 2014). Rule 81 enumerates "particular proceedings" to which the Rules do not automatically and fully apply, including price proceedings. FED. R. CIV. P. 81; cf. Application of Murra, 166 F.2d 605,606 (7th Cir. 1948) ("[T]his rule was for the purpose, as to the proceedings therein designated, of avoiding conflict between procedure prescribed by the rules and that prescribed by statute.").

45 FED. R. CIV. P. 1; $c f$. Grimm \& Yellin, supra note 8, at 525 (emphasizing that Rule 1's goals cannot be realized without cooperation amongst court, lawyers, and parties).

46 FED. R. CIV. P. 1 advisory committee's note to 1993 amendment; see also Lonnie T. Brown, Civility and Collegiality-Unreasonable Judicial Expectations for Lawyers as Officers of the Court?, 2 St. MARY's J. LEGAL MALPRACTICE \& ETHICS 324, 342-43 (2012) (touching upon this addition's import).

47 FED. R. Civ. P. 1 advisory committee's note to 1993 amendment; Kmart Corp. v. Kroger Co., No. 1:11-CV-00103-GHD-DAS, 2014 U.S. Dist. LEXIS 10115, at*2-3, 2014 WL 309485, at*1 (N.D. Miss. Jan. 28, 2014).

48 FED. R. Civ. P. 1 advisory committee's note to 2015 amendment; Navico, Inc. v. Garmin Int'1 Inc., No. 14-cv-303-CVE-TLW, 2015 U.S. Dist. LEXIS 160036, at*15, 2015 WL 7721218, at *5 (N.D. Okla. Nov. 30, 2015). 
this obligation to parties as well. ${ }^{49}$ In light of these revisions, every rule must be read and applied so as to realize the three values - justice, speed, and inexpensiveness - enthroned in Rule 1's hortatory sentence. ${ }^{50}$ Significantly, courts have drawn further support for this interpretive direction from their vision of ideal discovery as "relatively collegial, timely, and productive" misuse, and abuse of procedural tools that increase cost and result in delay." 52

Setting forth the Rules' "pre-trial deposition-discovery mechanism" 53 since $1970,{ }^{54}$ two subsections directly relevant to a party's deposition-related duties appear in Rule 26. Rule 26(b)(1) fixes discovery's famously minimal relevance standard-"Parties may obtain discovery regarding any nonprivileged matter that is relevant to any party's claim or defense" - and entitles a court to order "discovery of any

49 FED. R. CIV. P. 1 advisory committee's note to 2015 amendment ("[J]ust as the court should construe and administer these rules to secure the just, speedy, and inexpensive determination of every action, so the parties share the responsibility to employ the rules in the same way."); Paul v. State Farm. Mut. Auto. Ins. Co., No. 2:14-cv-1382, 2015 U.S. Dist. LEXIS 143935, at*12, 2015 WL 6134104, at*5 (W.D. Pa. Oct. 16, 2015).

50 See, e.g., The Scotch Whisky Ass'n v. U.S. Distilled Prods. Co., 952 F.2d 1317, 1319 (Fed. Cir. 1991) ("Rule 1 sets the policy for construing all of these rules."); United States v. Hoffa, 497 F.2d 294, 296 (7th Cir. 1974) ("All of the Federal Rules of Civil Procedure, including Rule 54(d) relating to costs, must be interpreted in light of Rule 1."); Nasser v. Isthmian Lines, 331 F.2d 124, 127 (2d Cir. 1964) ("[T]he Rules were intended to embody a unitary concept of efficient and meaningful judicial procedure, and that no single Rule can consequently be considered in a vacuum."); Paul J. McArdle, A Short and Plain Statement: The Significance of Leatherman v. Tarrant County, 72 U. DET. MERCY L. REV. 19, 44 (1994) ("It must be recognized that the system of the Federal Rules was designed as an integrated whole.").

51 Matthew L. Jarvey, Note, Boilerplate Discovery Objections: How They Are Used, Why They Are Wrong, and What We Can Do About Them, 61 DraKe L. Rev. 913, 919 (2013).

52 FED. R. CIV. P. 1 advisory committee's note to 2015 amendment; see also Jean M. Cary, Rambo Depositions: Controlling an Ethical Cancer in Civil Litigation, 25 HofsTRA L. REV. 561, 579-92 (1996) (discussing the mechanisms provided by the Rules for remedying "Rambo behavior in depositions" before 1996). That this cooperative norm may be in conflict with the lawyers' adversarial instincts has not escaped notice. Beckerman, supra note 8 , at 521 . The emphasis placed upon this principle by courts and advisory committees, as well as the removal of references to zealous advocacy in many modern code of ethics, may eventually prompt lawyers to adhere to a cooperative, anti-obstructive in discovery and reserve their zealousness for a trial's cauldron. See, e.g., ALASKA R. CIV. P. 30(d)(1); Ark. R. Civ. P. 30(d)(1); Fla. R. Civ. P. 1.310(c); Mass. R. Civ. P. 30(c); MD. R. Civ. P. CiR. CT. 2-415(g); MinN. R. Civ. P. 30.04(a); R.I. R. CIV. P. 30(d)(1); TENN. R. Civ. P. 30.03; Tex. R. Civ. P. 199.5(d). At the very least, many so hope. See Judith L. Maute, Sporting Theory of Justice: Taming Adversary Zeal with a Logical Sanctions Doctrine, 20 CONN. L. ReV. 7, 10 (1987).

53 Hickman v. Taylor, 329 U.S. 495, 500, 67 S. Ct. 385, 388, 91 L. Ed. 451, 457 (1947).

54 FED. R. CIV. P. 26 advisory committee's note to 1970 amendment. Beforehand, Rule 26 contained the Rules' deposition-specific provisions. Id. 
matter relevant to the subject matter involved in the action" upon a showing of "good cause." 55 Additionally, the body of Rule 26(b)(1) now encodes the proportionality standard that was extracted from Rule 26(b)(1) and placed in Rule 26(b)(2)(C) in 1983. ${ }^{56}$ As a result, more clearly than ever before, potential evidence's discoverability is dependent upon its "proportional[ity] to the needs of the case, considering the importance of the issues at stake in the action, the amount in controversy, the parties' relative access to relevant information, the parties' resources, the importance of the discovery in resolving the issues, and whether the burden or expense of the proposed discovery outweighs its likely benefit." ${ }^{57}$ Concomitantly, Rule 26(b)(1) severs any link between relevance for purposes of discovery and admissibility: "Information within this scope of discovery need not be admissible in evidence to be discoverable," 58 a once express limit_-"Relevant information need not be admissible at the trial if the discovery appears reasonably calculated to lead to the discovery of admissible evidence"-thusly eliminated as of December 1, 2015..$^{59}$ With the breadth of Rule 1 and Rule 26(b)(1)

55 FED. R. CIV. P. 26(b)(1); see also, e.g., U.S. CFTC v. Parnon Energy, Inc., 593 F. App'x 32, 36 (2d Cir. 2014) ("Relevance to the subject matter under Rule 26 is 'construed broadly to encompass any matter that bears on, or that reasonably could lead to other matter that could bear on, any issue that is or may be in the case." (quoting Oppenheimer Fund v. Sanders, 437 U.S. 340, 351, 98 S. Ct. 2380, 2389, 57 L. Ed. 2d 253, 265 (1978))); Lewis v. ACB Bus. Servs., Inc., 135 F.3d 389, 402 (6th Cir. 1998) ("The scope of discovery under the Federal Rules of Civil Procedure is traditionally quite broad."); Teichgraeber v. Memorial Union Corp. of Emporia State Univ., 932 F. Supp. 1263, 1265 (D. Kan. 1996) ("Discovery relevance is minimal relevance, which means it is possible and reasonably calculated that the request will lead to the discovery of admissible evidence." (citation omitted) (internal quotation marks omitted)). Notably, Rule 26's original scope of "any subject matter" was later modified to "any claim or defense." FED. R. CIV. P. 26 advisory committee's note to 2000 amendment; see also Walker v. State Farm. Mut. Auto. Ins. Co., No. 5:11-0529, 2012 U.S. Dist. LEXIS 48476, at *28-30, 2012 WL 1155140, at*8-9 (S.D. W. Va. Apr. 5, 2012) (discussing the effect of this change). Among others, the impetus for this change was the perceived abuse of the Rules' liberalized discovery framework. See, e.g., Richard L. Marcus, Discovery Containment Redux, 39 B.C. L. REV. 747, 752 (1998).

56 FED. R. CIV. P. 26(b)(1); FED. R. CIV. P. 26 advisory committee's note to 2015 amendment. As most of the same proportionality factors had been originally placed in Rule 26(b)(1) in 1983 and removed to Rule 26(b)(2)(C)(ii) in 1993, the most recent amendments restored rather than supplemented. FED. R. CIV. P. 23 advisory committee's note to 2015 amendment. The shift, seemingly, had "softened, although inadvertently," the "clear focus of the 1983 provisions" limiting discovery so as to "deal with the problem of overdiscovery." Id. at 22.

57 FED. R. CIV. P. 26(b)(1); Booth v. City of Dallas, 312 F.R.D. 427, 430 (N.D. Tex. 2015) (quoting new rule).

58 FED. R. CIV. P. 26(b)(1); Anderson v. Marsh, 312 F.R.D. 584, 588 (E.D. Cal. 2015) (citing new rule).

59 FED. R. CIV. P. 26(b)(1) (amended Dec. 1, 2015); SEC v. Rajaratnam, 622 F.3d 159, 181 (2d Cir. 2010); Flora v. Hamilton, 81 F.R.D. 576, 577-78 (M.D.N.C. 1978). The reasons for this change reveal the continuing potency of discovery's liberality, as the phrase 
conspicuous, their linked criteria for verifying data's relevance and assembling evidence so classified extends to depositions of parties and non-parties alike. ${ }^{60}$

Beyond according new prominence to an old test, Rule 26(b)(1) subjects "[a]ll discovery," whether or not a dispute has arisen, to the limitations imposed by Rule $26(\mathrm{~b})(2)(\mathrm{C}) \cdot{ }^{61}$ Consequently, several constraints - "the discovery sought is unreasonably cumulative or duplicative, or can be obtained from some other source that is more convenient, less burdensome, or less expensive;" "the party seeking discovery has had ample opportunity to obtain the information by discovery in the action;" or "the burden or expense of the proposed discovery outweighs its likely benefit, considering the needs of the case, the amount in controversy, the parties' resources, the importance of the issues at stake in the action, and the importance of the discovery in resolving the issues" ${ }^{\prime 2}$ — cannot be ignored if a potential deponent chooses to oppose a notice or subpoena or terminate a suddenly unpleasant colloquy. ${ }^{63}$ Even absent such an action, a court may invoke Rule

deleted had been "used by some, incorrectly, to define the scope of discovery." FED. R. CIV. P. 26 advisory committee's note to 2015 amendment.

60 Bell v. Bd. of Educ., 225 F.R.D. 186, 193 (S.D. W. Va. 2004); see also, e.g., Pucket v. Hot Springs Sch. Dist. No. 23-2, 239 F.R.D. 572, 579 (D.S.D. 2006); Credit Lyonnais, S.A. v. SGC Int'l, Inc., 160 F.3d 428, 430 (8th Cir. 1998); cf. Watts v. SEC, 482 F.3d 501, 507 (D.C. Cir. 2007) (observing that Rule 26 constrains the reach of a subpoena issued pursuant to Rule 45). This symbiotic understanding has never altered. See Edson R. Sunderland, Discovery Before Trial Under the New Federal Rules, 15 TENN. L. REV. 737, 743-44 (1939) (explaining the scope of the discovery examination permitted by Rule 26(b), imported into Rule 30(a) and (b) in 1970).

61 Fed. R. Civ. P. 26(b)(1); see also, e.g., Progressive Cas. Ins. Co. v. FDIC, 49 F. Supp. 3d 545, 562 (N.D. Iowa 2014); Colaco v. ASIC Advantage Simplified Pension Plan, 301 F.R.D. 431, 434 n.21 (N.D. Cal. 2014); cf. United States ex rel. Carter v. Bridgepoint Educ., Inc., 305 F.R.D. 225, 237-40 (S.D. Cal. 2015). Conceptually, the distinction between Rule 26(b)(1) and (b)(2)(C) is highly technical: while the proportional language in Rule 26(b)(1) circumscribes discovery's scope and thus what a party may ask for from another, the factors in Rule 26(b)(2)(C)(i)-(ii) allow a court to limit production of evidence already within the scope of Rule 26(b)(1). That is, the evidence must first fall within Rule 26(b)(1) before Rule 26(b)(2)(C) can be utilized to foreclose discovery. However, the two sections effectively operate in tandem, so that any requested material's actual release or question's ultimate answer will depend on whether the request or question both meets the relevance and proportionality criteria in Rule 26(b)(1) and does not fall within the verboten categories in Rule 26(b)(2)(C). Indeed, Rule 26(b)(2)(C) specifically allows a court to limit discovery "outside the scope permitted by Rule 26(b)(1)." FED. R. CIV. P. 26(b)(2)(C)(iii).

62 FED. R. Civ. P. 26(b)(2)(C). Unchanged in 2015, Rule 26(b)(2)(C) now further buttresses the balancing test formally appended to Rule 26(b)(1) on December 1, 2015. See also Morris, supra note 35, at 146-47.

63 FED. R. CIV. P. 26(b)(1), 30(d)(3)(B); see also, e.g., Kiln Underwriting, Ltd. v. Jesuit High Sch. of New Orleans, Nos. 05-04350c, 06-05060, 06-05057 Section "R" (4), 2008 U.S. Dist. LEXIS 83535, at *4-6, 2008 WL 4286491, at *2 (E.D. La. Sept. 18, 2008) (considering whether to limit a Rule 30 deposition pursuant to former Rule 26(b)(2)(C) in 
26(b)(2)(C) sua sponte, ${ }^{64}$ any such analysis incorporating the relevance and proportionality gauges lodged in Rule $26(\mathrm{~b})(1) .{ }^{65}$

Considering Rules 1 and 26's universal reach and discretionary character, the possibility of conflict in any rules' interpretation and administration based on a peculiar constellation of facts ever lurks. For decades, the Rules have treated the most assiduous utilization of discovery's foremost riggings - the deposition, requests for admission, interrogatories, and production of documents - with benign tolerance. Nevertheless, the right to employ this foursome in pursuit of even plainly relevant discovery may today be circumscribed pursuant to Rule 1's second clause, ${ }^{66}$ Rule 26(b)(1), ${ }^{67}$ and Rule 26(b)(2)(C), ${ }^{68}$ control of discovery mostly left to the trial court's sound discretion. ${ }^{69}$ By virtue of this development, a complaint that the Rules' first drafters sought to

light of the scope of discovery specified in Rule 26(b)(1)); Flanagan v. Wyndham Int'l, 231 F.R.D. 98, 102 (D.D.C. 2005) (observing that per Rule 26(b)(1) "[a] party is entitled to depose a witness on all relevant issues as to which the witness has knowledge" (alteration in original) (internal quotation marks omitted)); CBS, Inc. v. Ahern, 102 F.R.D. 820, 822 (S.D.N.Y. 1984) ("A party is entitled to depose a witness on all relevant issues as to which the witness has knowledge."). "[C]ollect[ing] all provisions bearing on requirements of leave of court to take a deposition," Rule 30(a)(2) explicitly compels application of the factors enumerated in Rule 26(b)(2) if leave of court is required for a deposition to be held. FED. R. CIV. P. 30(a) advisory committee's note to 1993 amendment; FED. R. CIV. P. $30(a)(2)$

64 FED. R. CIV. P. 26(b)(2)(C) (requiring a court to "limit the frequency or extent of discovery" whether on "motion or on its own"); see also, e.g., Sec. Nat'l Bank v. Jones Day, 800 F.3d 936, 942 (8th Cir. 2015); Rich v. Shrader, No. 09-CV-0652-AJB (BGS), 2013 U.S. Dist. LEXIS 98184, at*15, 2013 WL 3710806, at*5 (S.D. Cal. July 11, 2013).

65 Fed. R. Civ. P. 26(b)(2)(C)(i)-(iii); see Charvat v. Travel Servs, 110 F. Supp. 3d 894, 897 (N.D. Ill. 2015) (contending that, in part due to Rule 26(b)(2)(C), "a court is not merely permitted to limit discovery of information it finds to be irrelevant[, as defined in Rule 26(b)(1)], it is required to do so").

66 See, e.g., Biovail Labs., Inc. v. Anchen Pharm., Inc., 233 F.R.D. 648, 651-52 (C.D. Cal. 2006); Van Pilsum v. Iowa State Univ. of Sci. \& Tech., 152 F.R.D. 179, 181 (S.D. Iowa 1993).

67 FED. R. Civ. P. 26(b)(1).

68 Amini Innovation Corp. v. McFerran Home Furnishings, Inc., 300 F.R.D. 406, 409 (C.D. Cal. 2014); see also Robinson v. Horizon Blue Cross-Blue Shield, No. 2:12-CV02981-ES-JAD, 2013 U.S. Dist. LEXIS 180325, at *4-6, 2013 WL 6858956, at *2 (D.N.J. Dec. 23, 2013) (observing that Rule 26 "defines the bounds of relevant discovery" and "sets out the parameters for when the Court must limit discovery" in, among other subparagraphs, $(\mathrm{b})(2)(\mathrm{C}))$.

69 E.g., Doe v. Lexington-Fayette Urban Cnty. Gov't, 407 F.3d 755, 760-61 (6th Cir. 2005); Motley v. Marathon Oil Co., 71 F.3d 1547, 1550 (10th Cir. 1995); Cruden v. Bank of New York, 957 F.2d 961, 972 (2d Cir. 1992); Mayo v. Tr-Bell Indus., Inc., 787 F.2d 1007, 1012 (5th Cir. 1986). 
neuter ${ }^{70}$ has been reinvigorated, many courts again declaring: "Discovery should not serve as a fishing expedition ...."71

\section{Special Class of Depositions (Rule 27)}

Of use only before an action is filed or pending an appeal, Rule 27 licenses depositions to perpetuate testimony. ${ }^{72}$ For Rule 27 to apply, the petitioner must "show that there is a risk of loss of the desired testimony," 73 its "immediate taking" essential "to preserve it for future use." "74 When it was devised, it emulated "equity practice" and then "modern statutes." 75

Rule 27(a) governs prior to an action's commencement. It first requires that a person file a verified petition, titled in their name, in the adverse party's resident district specifically asking for an order authorizing the latter's deposition. ${ }^{76}$ The petition itself must meet five separate requirements and be served on the expected adverse party, with a notice stating the proposed hearing's time and place, at least twenty-one days before the hearing date. ${ }^{77}$ If the court is satisfied that "perpetuating the testimony may prevent a failure or delay of justice," an order must issue designating the persons to be deposed and specifying its subjectmatter and mode. ${ }^{78}$ Hereafter, the deposition may proceed within the

70 See cases cited supra notes 33-34.

71 Smith v. Lyons, Doughty \& Velduius, P.C., Civ. No. 07-5139, 2008 U.S. Dist LEXIS 56725, at *16, 2008 WL 2885887, at *5 (D.N.J. July 23, 2008); accord, e.g., Plexicoat Am. LLC v. PPG Architectural Finishes, Inc., No. 13-cv-3887, 2015 U.S. Dist. LEXIS 4190, at *5, 2015 WL 171831, at *2 (E.D. Pa. Jan. 14, 2015); Rubin v. Islamic Republic of Iran, 349 F. Supp. 2d 1108, 1111 (N.D. Ill. 2004); cf. Bayer AG v. Betachem, Inc., 173 F.3d 188, 191 (3d Cir. 1999) ("Although the scope of discovery under the Federal Rules is unquestionably broad, this right is not unlimited and may be circumscribed.").

72 FED. R. CIV. P. 27; Sunderland, supra note 60, at 740 (describing Rule 27 as "concurrent" with "state methods for perpetuating testimony").

73 Kunimoto v. Lehman (In re Kunimoto), No. 96ms232 (AER), 1996 U.S. Dist. LEXIS 15784, at *5-6, 1996 WL 622094, at*2 (D.D.C. Oct. 16, 1996); accord Penn. Mut. Life Ins. Co. v. United States, 68 F.3d 1371, 1374-75 (D.C. Cir. 1995); see also, e.g., Cent. States v. Nagy Ready Mix, Inc., No. $10 \mathrm{cv}$ 0358, 2012 U.S. Dist. LEXIS 181942, at *3, 2012 WL 6720447, at *1 (N.D. Ill. Dec. 27, 2012) ("This rule is not a substitute for discovery-its purpose is to perpetuate known testimony, not to discover unknown testimony."); Ash v. Cort, 512 F.2d 909, 911 (3d Cir. 1975) ("Rule 27 properly applies only in that special category of cases where it is necessary to prevent testimony from being lost.").

74 In re Yamaha Motor Corp., 251 F.R.D. 97, 98 (N.D.N.Y. 2008).

75 FED. R. CIV. P. 27 advisory committee's note (1938).

76 Fed. R. CIV. P. 27(a)(1); Advanced Orthopedic Designs, L.L.C. v. Shinseki, 886 F. Supp. 2d 546, 554 n.57 (W.D. Tex. 2012).

77 FED. R. CIV. P. 27(a)(1)(A)-(E), (2); In re Blow Wind Shipping Ltd., 267 F.R.D. 32, 33 (D. Me. 2010).

78 FeD. R. CIV. P. 27(a)(3); PegaSync Techs., Inc. v. Payros, No. 14-MC-50440, 2014 U.S. Dist. LEXIS 82728, at *2, 2014 WL 2763620, at*1 (E.D. Mich. June 18, 2014). A 
parameters of Rules 30 or 31, a court enabled to issue any necessary orders pursuant to Rules 34 and $35 .^{79}$ Once taken, a Rule 27(a) deposition may be utilized, as permitted by Rule 32(a), ${ }^{80}$ in any "later-filed district courtaction involving the same subject matter if the deposition either was taken under these rules or, although not so taken, would be admissible in evidence in the courts of the state where it was taken."

Rule 27(b) applies to depositions "if an appeal has been taken or may still be taken." 82 A party must move for leave to take such depositions, complying with the same notice and service requirements "as if the action were pending in the district court." 83 The motion so requesting must indicate "the name, address, and expected substance of the testimony of each deponent" and outline "the reasons for perpetuating the testimony." ${ }^{\text {" }}$ Upon applying the same standard specified in Rule 27(a)(3) - "to avoid [a] failure or delay of justice" - a court may authorize the taking of these depositions, issuing any order permitted under Rules 34 and $35{ }^{85}$ Rule 27(b) depositions may be used "as any other deposition taken in a pending district-court action."

similar standard - "in the interest of justice" - appears in the statute governing depositions of a United States national or resident who is in a foreign country. 28 U.S.C. $\S 1783$ (a) (2014); Air Turbine Tech., Inc. v. Atlas Copco AB, 217 F.R.D. 545, 546 (S.D. Fla. 2003).

79 FeD. R. CIV. P. 27(a)(3); In re Kubler, No. MC 11-0058 JB, 2012 U.S. Dist. LEXIS 14206, at *20, 2012 WL 394680, at *6 (D.N.M. Jan. 25, 2012). Rule 34 concerns the production of documents, electronically stored information, and tangible things as well as the right to enter onto land for inspection and other purposes. FED. R. CIV. P. 34; McKelvey v. W. Reg'l Jail, No. 3:13-CV-22206, 2015 U.S. Dist. LEXIS 59746, at*19-20, 2015 WL 2144668, at *6-7 (S.D. W. Va. May 7, 2015). "The court where the action is pending may order a party whose mental or physical condition - including blood group - is in controversy to submit to a physical or mental examination by a suitably licensed or certified examiner." FeD. R. Civ. P. 35(a)(1); Cottle v. Nev. Dep't of Corr., No. 3:12-cv-00645MMD-WGC, 2013 U.S. Dist. LEXIS 152935, at*3-4, 2013 WL 5773845, at*1 (D. Nev. Oct. 24, 2013).

80 FED. R. CIV. P. 32(a)(1) (specifying the conditions for a deposition's use); see infra Part II.B.4.

81 FeD. R. Civ. P. 27(a)(4); N. States Power Co. v. City of Ashland, No. 12-cv-602bbc, 2015 U.S. Dist. LEXIS 50022, at*17, 2015 WL 1745880, at*7 (W.D. Wis. Apr. 16, 2015).

82 FED. R. CIV. P. 27(b)(1); Citibank, N.A. v. Jamil, No. 11-11655-PBS, 2012 U.S. Dist. LEXIS 135917, at*2-3, 2012 WL 4390794, at*1 (D. Mass. Sept. 21, 2012).

83 Fed. R. CIV. P. 27(b)(2); Sanchez v. Chappell, No. 1:97-CV-06134-AWI-SAB, 2015 U.S. Dist. LEXIS 96408, at*389-90, 2015 WL 4496379, at*156 (E.D. Cal. July 23, 2015).

84 Fed. R. CIv. P. 27(b)(2); Norex Petroleum, Ltd. v. Access Indus., 620 F. Supp. 2d 587, 590 (S.D.N.Y. 2009).

85 FED. R. Civ. P. 27(b)(3); Lampton v. Diaz, No. 3:09cv324-DPJ-MTP, 2010 U.S.

Dist. LEXIS 119966, at*10-11, 2010 WL 4338650, at *2 (S.D. Miss. Oct. 26, 2010).

86 FeD. R. CIV. P. 27(b)(3); Murr v. Stinson, 582 F. Supp. 230, 231 (E.D. Tenn. 1984) (listing non-examples). 
Meant to aid in the eventual adjudication of substantive rights, ${ }^{87}$ Rule 27 offers "a simple method of perpetuating testimony." ${ }^{88}$ Notwithstanding this fact, because its ambit is narrower than that delimitated by Rule 30 or $31,{ }^{89}$ Rule 27 cannot substitute for general discovery. ${ }^{90}$ More importantly, in the interval after a case's filing but before its appeal, the interplay between Rules 26 and either Rule 30 if an oral deposition is sought or Rule 31 if a written one is desired controls. ${ }^{91}$

\section{Deposition Procedures (Rules 30 and 31)}

Whether taken for purposes of trial or discovery, ${ }^{92}$ Rule 30 regulates the oral deposition, that "most potent and searching means of discovery." 93 "Without leave," though subject to specifically enumerated and narrowly construed exceptions, a party in a filed suit may examine "any person," including but not limited to a party, "by oral questions." 94 If necessary or if desired, attendance may be ensured by means of a subpoena under Rule

87 Mosseller v. United States, 158 F.2d 380, 382 (2d Cir. 1946), cited in, e.g., Reynolds v. Am. Express Entity One, No. 7:09CV00228, 2009 U.S. Dist. LEXIS 73893, at *3-4, 2009 WL 2578964, at*1 (W.D. Va. Aug. 20, 2009); Deiulemar Campagnia di Navigazione S.P.A. v. M/V Allegra, 198 F.3d 473, 484 (4th Cir. 1999).

88 FED. R. CIV. P. 27 advisory committee's note (1938).

89 Ash v. Cort, 512 F.2d 909, 911 (3d Cir. 1975); see also, e.g., Robinson v. Winslow Twp., No. 10-2824 (JHR/JS), 2010 U.S. Dist. LEXIS 86248, at *7-8, 2010 WL 3326678, at *2-3 (D.N.J. Aug. 23, 2010).

90 Biddulph v. United States, 239 F.R.D. 291, 293 (D.D.C. 2007); see also, e.g., In re Petition of Austin, No. 13mc252, 2013 U.S. Dist. LEXIS 100760, at*3, 2013 WL 5255125, at *1 (S.D.N.Y. July 16, 2013); Deiulemar, 198 F.3d at 485-86; In re Storck, 179 F.R.D. 57, 58 (D. Mass. 1998); In re Ford, 170 F.R.D. 504, 506-07 (M.D. Ala. 1997); Penn Mut. Life Ins. Co. v. United States, 68 F.3d 1371, 1376 (D.C. Cir. 1995).

91 19th St. Baptist Church v. St. Peters Episcopal Church, 190 F.R.D. 345, 348 (E.D. Pa. 2003). Rule 56(d) may also occasionally apply. FED. R. CIV. P. 56(d); Schulze v. FBI, No. 1:05-cv-00180 AWI GSA, 2011 U.S. Dist. LEXIS 5688, at *4-5, 2011 WL 129716, at *2 (E.D. Cal. Jan. 14, 2011); cf. RadLAX Gateway Hotel, LLC v. Amalgamated Bank, 132 S. Ct. 2065, 2071, 180 L. Ed 2d 967, 974 (2012) ("The general/specific canon . . . has full application ... to statutes . . . in which a general authorization and a more limited, specific authorization exist side-by-side. There the canon avoids not contradiction but the superfluity of a specific provision that is swallowed by the general one.").

92 See, e.g., Chrysler Int'l Corp. v. Chemaly, 280 F.3d 1358, 1362 n.8 (11th Cir. 2002); Estenfelder v. Gates Corp., 199 F.R.D. 351, 353 (D. Colo. 2001); Integra Lifesciences I, Ltd. v. Merck, 190 F.R.D. 556, 558 (S.D. Cal. 1999); Tatman v. Collins, 938 F.2d 509, 510-11 (4th Cir. 1991); Keller v. Orion Ins. Co., 285 F. Supp. 906, 906-07 (D. Minn. 1968).

93 Alexander Holtzoff, Instruments of Discovery Under Federal Rules of Civil Procedure, 41 Mich. L. REV. 205, 206 (1942).

94 Fed. R. CIV. P. 30(a)(1); Lefkoe v. Jos. A. Bank Clothiers, Inc., 577 F.3d 240, 246 (4th Cir. 2009); Sunderland, supra note 60, at 741 (describing the right to a deposition to be "absolute and unconditional, except that if the deposition is desired before answer served, leave of court must be obtained" and emphasizing that the right is "ordinarily to be exercised on mere notice"). Rule 30(a)(2) lists the exceptions. FED. R. CIV. P. 30(a)(2); I/P Engine, Inc. v. AOL, Inc., 283 F.R.D. 322, 323 (E.D. Va. 2012). 
$45 .{ }^{95}$ Rule 30 's formal requirements plentiful, ${ }^{96}$ "examination and crossexamination of a deponent proceed as they would at trial under the Federal Rules of Evidence, except Rules 103 and 615." $" 97$ In general, a witness possesses "the same rights and privileges as would a witness testifying in court at a trial." 98

At the same time, once a deposition has commenced, Rules 30(c) limits the non-deposing party's maneuverability. While "[a]n objection at the time of the examination - whether to evidence, to a party's conduct, to the officer's qualifications, to the manner of taking the deposition, or to any other aspect of the deposition-must be noted on the record . . the examination still proceeds . . . subject to any [such] objection." "99 Only an objection voiced so as to preserve a privilege, enforce a court's own limitation, or to present a motion under Rule 30(d)(3) to terminate or limit a deposition "on the ground that it is being conducted in bad faith or in a manner that unreasonably annoys, embarrasses, or oppresses the deponent or party" 100 entitles the deponent to refuse to answer and a lawyer to so

95 FED. R. Civ. P. 30(a)(1). A party may be deposed purely by notice. United States v. $\$ 160,066.98$ from Bank of Am., 202 F.R.D. 624, 627 (S.D. Cal. 2001); see also, e.g., Calderon v. Experian Info. Solutions, Inc., 287 F.R.D. 629, 631 (D. Idaho 2012) ("It is, of course, black letter law that only a party to a lawsuit may be deposed pursuant to notice as opposed to subpoena."). If they do not consent, non-parties may only be deposed via subpoena. FED. R. CIV. P. 30 advisory committee's note to 1971 amendment; Lehman v. Kornblau, 206 F.R.D. 345, 346 (E.D.N.Y. 2001) ("Discovery of non-parties must be conducted by subpoena pursuant to Fed. R. Civ. P. 45, not the rules governing discovery of parties."); $c f$. Moon v. SCP Pool Corp., 232 F.R.D. 633, 636 (C.D. Cal. 2005) (concluding that once a non-party is served in accordance with Rule 45, it is under the same obligation that would be conferred on a party to whom request is addressed pursuant to Rule 30).

96 Fed. R. Civ. P. 30(b); Am. Cas. Co. v. Krieger, 160 F.R.D. 582, 585 (S.D. Cal. 1995).

97 Fed. R. CIV. P. 30(c)(1); FCC v. Mizuho Medy Co., 257 F.R.D. 679, 681 (S.D. Cal. 2009).

98 8A Charles A. Wright et Al., Federal Practice and Procedure $§ 2113$ (2d ed. 1994); see also Soule v. RSC Equip. Rental, Inc., No. 11-2022 Section "E" (3), 2012 U.S. Dist. LEXIS 150078, at*6, 2012 WL 5060059, at *2 (E.D. La. Oct. 18, 2012).

99 Fed. R. Civ. P. 30(c)(2); Sec. Nat'l Bank of Sioux City v. Abbott Labs., 299 F.R.D. 595, 602 (N.D. Iowa 2014), rev'd, 800 F.3d 936 (8th Cir. 2015). The Eighth Circuit reversed not because the behavior was not sanctionable but because no advance notice had been given of the unusual nature of the sanctions being considered. 800 F.3d at 944 .

100 FeD. R. CIV. P. 30(d)(3)(A) (emphasis added); D.A. v. Meridian Joint Sch. Dist. No. 2., 289 F.R.D. 614, 633 (D. Idaho. 2013). If a party "so demands," the deposition is suspended "for the time necessary to obtain an order" from the appropriate court. FED. R. Civ. P. 30(d)(3)(A); Bozic v. City of Wash., Pa., 912 F. Supp. 2d 257, 278 (W.D. Pa. 2012) (observing that "[i]f [d] efendant's counsel believed the deposition had become so hostile to the witness that it could not and should not continue, the proper remedy was to suspend the deposition and seek an immediate protective order of this Court, rather than to engage in the self-help of simply walking out"). 
instruct. ${ }^{101}$ Hence, outside of a privilege ${ }^{102}$ being threatened or a judicial order being flouted, only "the manner in which the interrogation is conducted" may constitute "[a] ground[] for refusing to proceed, followed by the required motion to seek relief." 103

The confusing final word in its original title-_"Interrogatories"swapped with a far more accurate one-"Questions"-in 1970, ${ }^{104}$ Rule 31 authorizes "but another method of obtaining the same information that might be procured by an oral examination" under Rule $30{ }^{105}$ Little changed in substance since its formulation, Rule 31 permits a party to "depose any person, including a party[,]" by use of written questions "without leave of court except as provided in Rule 31(a)(2)." "106 Such leave must be obtained, "to the extent consistent with Rule 26(b)(2)," if either the deponent is imprisoned or both "the parties have not stipulated to the deposition" and one of any three facts is proven: "(i) the deposition would result in more than 10 depositions being taken under this rule or Rule 30 by the plaintiffs, or by the defendants, or by the third-party defendants; (ii) the deponent has already been deposed in the case; or (iii) the party seeks to take a deposition before the time specified in Rule 26(d)., ${ }^{, 107}$ If a party opts to use Rule 31, the written questions must be served on every other party with a notice containing the details specified in Rule 31(a)(3). ${ }^{108}$ "[S]ervice of all questions, including cross, redirect, and recross, is to be made on all parties," thereby "enabl[ing all] . . to participate fully in the

101 Fed. R. Civ. P. 30(c)(2); Gober v. City of Leesburg, 197 F.R.D. 519, 520 (M.D. Fla. 2000). For the different privileges often recognized as falling within this exception, see 7 James WM. MoOre et AL., MoOre’s Federal Practice 30.43[2] (3d ed. 1999).

102 The cogency of a particular claim of privilege will often depend upon the substantive law to be applied in the case at hand. See FED. R. EVID. 501.

103 In re Stratosphere Corp. Secs. Litig., 182 F.R.D. 614, 619 (D. Nev. 1998); see also, e.g., Rangel v. Gonzalez Mascorro, 274 F.R.D. 585, 591 (S.D. Tex. 2011); In re Omeprazole Patent Litig., 227 F.R.D. 227, 230 (S.D.N.Y. 2005); Smith v. Logansport Cmty. Sch. Corp., 139 F.R.D. 637, 643 (N.D. Ind. 1991).

104 FED. R. CIV. P. 31 advisory committee's note to 1970 amendment; In re Ishihara Chem. Co., 121 F. Supp. 2d 209, 222 n.10 (S.D.N.Y. 2000).

105 Cronan v. Dewavrin, 9 F.R.D. 337, 339 (S.D.N.Y. 1949).

106 FeD. R. Civ. P. 31(a)(1); Krause v. Nev. Mut. Ins. Co., No. 2:12-cv-00342-JCMCWH, 2013 U.S. Dist. LEXIS 180049, at *5-6, 2013 WL 6632628, at *2 (D. Nev. Dec. 16, 2013).

107 FED. R. Civ. P. 31(a)(2)(A)-(B); Ciempa v. Jones, No. 08-CV-0685-CVE-TLW, 2011 U.S. Dist. LEXIS 889, at *4, 2011 WL 52480, at *2 (N.D. Okla. Jan. 4, 2011).

108 Fed. R. Civ. P. 31(a)(3); Miami-Dade Cnty. v. Schindler Elevator Corp., No. 1021469-CIV-UNGARO, 2011 U.S. Dist. LEXIS 25044, at *4, 2011 WL 765961, at *2 (S.D. Fla. Feb. 25, 2011); Spaeth v. Warner Bros. Pictures, 1 F.R.D. 729, 731 (S.D.N.Y. 1941). Rule 30(b)(6) governs questions directed to an organization per Rule 31(a)(4). FED. R. CIV. P. 31(a)(4); Duhn Oil Tool, Inc. v. Cooper Cameron Corp., No. 1:05-cv-01411 OWW GSA, 2009 U.S. Dist. LEXIS 100667, at*10, 2009 WL 3381055, at*4 (E.D. Cal. Oct. 15, 2009). 
procedure." 109 Practically speaking, for a deposition pursuant to Rule 31 to be subsequently useful and "to save expense and time," 110 written questions ought to "be carefully constructed to elicit specific facts, not conclusory generalities."111

Upon these questions' service, other obligations are triggered. Naturally, the parties' chosen officer must first be given copies of "all the questions served and of the notice." "112 $\mathrm{He}$ or she must then "promptly proceed in the manner provided in Rule 30(c), (e), and (f): (1) to take the deponent's testimony . . . ; (2) prepare and certify the deposition; and (3) send it to the party, attaching a copy of the questions and of the notice."113 While Rule 31 says nothing more about this officer's duties, it has been construed as forbidding him or her from "add[ing] his [or her] own gratuitous comments on the demeanor of the witness or on answers or statements made by the witness other than those included" in the written questions. ${ }^{114}$ In these kind of depositions, "[the] counsel who prepared the written questions does not participate in the questioning," and "[t]he reading of the questions is done by the officer before whom the deposition is taken." 115 Rule 31 sets a precise schedule for "cross-questions" (14 days), "redirect questions" (7 days), and "recross-questions" (7 days); ${ }^{116} \mathrm{a}$ court retains the power "to extend or shorten" these deadlines "for good cause." 117 Meanwhile, the party who noticed the deposition "must notify

109 FED. R. CIV. P. 31 advisory committee's note to 1970 amendment.

110 J. C. Nichols Co. v. Mid-States Freight Lines, Inc., 9 F.R.D. 553, 554 (W.D. Mo. 1949); see also Cronan v. Dewavrin, 9 F.R.D. 337, 339 (S.D.N.Y. 1949) (describing written depositions as "investigatory for the purpose of ascertaining facts in order to prepare for trial rather than primarily the perpetuation of evidentiary matters").

111 Molignaro v. Dutton, 373 F.2d 729, 731 (5th Cir. 1967); accord Whitehurst v. United States, 231 F.R.D. 500, 502 (S.D. Tex. 2005).

112 Fed. R. CIV. P. 31(b); Harpool v. Beyer, No. CIV S-10-1253 MCE GGH P, 2012 U.S. Dist. LEXIS 20383, at*17-18, 2012 WL 530916, at*7 (E.D. Cal. Feb. 17, 2012)

113 Fed. R. Civ. P. 31(b)(1)-(3); Frazier v. Redding Police Dep't, No. CIV S-11-1351 GGH P, 2012 U.S. Dist. LEXIS 56779, at*2, 2012 WL 1413977, at*1 (E.D. Cal. Apr. 23, 2012).

114 Gill v. Stolow, 16 F.R.D. 9, 10 (S.D.N.Y. 1954); see also United States v. Salim, 664 F. Supp. 682, 692 (E.D.N.Y. 1987) (distinguishing Gill, 16 F.R.D. at 9).

115 Holt v. City of Dickson, No. 3:07-0727, 2011 U.S. Dist. LEXIS 98147, at *21, 2011 WL 3850479, at *6 (M.D. Tenn. Aug. 30, 2011).

116 FED. R. CIV. P. 31(a)(5). These timespans were expanded in 1970, experience having shown "the existing time limits . . . to be unrealistically short." FED. R. CIV. P. 31(a) advisory committee's note to 1970 amendment. Constriction followed. FED. R. CIV. P. 31(a) advisory committee's note to 1993 amendment.

117 Fed. R. CIV. P. 31(a)(5); Galaviz v. C.R. Eng. Inc., No. A-12-MC-82 LY, 2012 U.S. Dist. LEXIS 53866, at *6, 2012 WL 1313301, at *2 (W.D. Tex. Apr. 17, 2012); $c f$. Baron v. Leo Feist, Inc., 7 F.R.D. 71, 71-72 (S.D.N.Y. 1946). 
all other parties when it is completed," 118 but it is the party who "files the deposition [who] must promptly notify all other parties of the filing." 119

\section{General Restrictions on a Deposition's Use (Rule 32)}

Although Rules 30 and 31 provide for much freedom in the taking of depositions, Rule 32 imposes "restrictions . . . upon their use." 120 "In general," Rule 32(a) sets the relevant legal standard, allowing for the use of a deposition "against a party" at a trial or a hearing so long as "the party was present or represented at the taking of the deposition or had reasonable notice of it," "it is used to the extent it would be admissible under the Federal Rules of Evidence if the deponent were present and testifying," and "the use is allowed by Rule 32(a)(2) through (8)."121 Rule 32(a)(2) authorizes a deposition for purposes of contradiction or impeachment of "the deponent as a witness, or any other purpose allowed by the Federal Rules of Evidence." 122 "[F]or any purpose," an adverse party may utilize the deposition of "a party or anyone who, when deposed, was the party's officer, director, managing agent, or designee under Rule 30(b)(6) or 31(a)(4)."123 Rule 32(a)(4) defines an "unavailable witness," "whether or not a party," whose deposition testimony may then "be use[d] for any purpose", 124 "ph[r]ased in the disjunctive," a party need show only one of five categories for a witness to be classified as "unavailable" for this subsection's purposes. ${ }^{125}$ Supplementary restrictions are appended to depositions taken on short notice or if a deponent cannot obtain an attorney to represent him or her during the deposition despite "diligent efforts."

118 Fed. R. Civ. P. 31(c)(1) (emphasis added); Britt v. Rahana, No. 1:13-cv-01795WTL-DML, 2014 U.S. Dist. LEXIS 167779, at*18 (S.D. Ind. Dec. 3, 2014).

119 FED. R. CIV. P. 31(c)(2) (emphasis added).

120 Pike \& Willis, supra note 27, at 1187 (emphasis in original).

121 FeD. R. Civ. P. 32(a)(1); Sara Lee Corp. v. Kraft Foods, Inc., 276 F.R.D. 500, 502 (N.D. Ill. 2011) (noting that while "[p]arties at trial generally must prove their cases with live testimony rather than depositions," this rule "is subject to numerous exceptions," as reflected in Rule 32).

122 FeD. R. CIV. P. 32(a)(2); Ershowsky v. Freedman (In re Freedman), 431 B.R. 245, 255 (Bankr. S.D. Fla. 2010).

123 Fed. R. Civ. P. 32(a)(3); Nelson v. Am. Home Assurance Co., 824 F. Supp. 2d 909, 916 n.4 (D. Minn. 2011).

124 Fed. R. Civ. P. 32(a)(4); A.H. v. Evenflo Co., 579 F. App’x 649, 655 (10th Cir. 2014).

125 Chao v. Tyson Foods, Inc., 255 F.R.D. 560, 562 (N.D. Ala. 2009).

126 FeD. R. CIV. P. 32(a)(5)(A)-(B); Harris v. CRST Van Expedited, Inc., No. 13-CV119-LRR, 2015 U.S. Dist. LEXIS 6619, at*2, 2015 WL 268939, at*1 (N.D. Iowa Jan. 21, 2015) (citing Rule 32(a)(5)(A)); Forrester Envtl. Servs. v. Wheelabrator Techs., Inc., No. 10-cv-154-JL, 2012 U.S. Dist. LEXIS 48846, at *11 n.3, 2012 WL 1161125, at *3 n.3 (D.N.H. Apr. 6, 2012) (describing Rule 32(a)(5)(B) as "the only provision of the Federal Rules that affirmatively requires exclusion of a deposition taken without leave of court"). 
Rule 32(a) makes two more explicit allowances. First, substitution of a party under Rule 25 "does not affect the right to use a deposition previously taken." 127 Second, "lawfully taken" depositions "filed in any federal- or state-court action may be used in a later action involving the same subject matter between the same parties" or as allowed by the Federal Rules of Evidence. ${ }^{128}$

Presuming these hurdles have been cleared or these exceptions satisfied, Rule 32(c) delineates the requisite forms of presentation. ${ }^{129}$ Echoing Federal Rule of Evidence 106, ${ }^{130}$ "[i]f a party offers in evidence only part of a deposition, an adverse party may require the offeror to introduce other parts that in fairness should be considered with the part introduced, and any party may itself introduce any other parts." 131 Under Rule 32, a court retains considerable discretion in determining whether to admit deposition testimony ${ }^{132}$ as substantive evidence, ${ }^{133}$ no distinction extant "between discovery depositions and depositions for use at trial." 134

5. Deposition Objections: Manner (Rules 30) and Waiver (Rule 32)

Per Rule 30(c)(2), any objection must be "stated concisely in a nonargumentative and nonsuggestive manner," 135 a command meant to be

127 FED. R. CIV. P. 32(a)(7); In re Freedman, 431 B.R. at 255.

128 Fed. R. Civ. P. 32(a)(8); Perry v. City of Stamford, 996 F. Supp. 2d 74, 80 (D. Conn. 2014).

129 FED. R. CIV. P. 32(c); Berman v. Durkin, No. 9:13-CV-136 (LEK/RFT), 2014 U.S.

Dist. LEXIS 57613, at *15, 2014 WL 1666339, at*5 (N.D.N.Y. Apr. 25, 2014).

130 Compare FeD. R. CIV. P. 32(a)(6), with FeD. R. Evid. 106; see also Mattocks v. Daylin, Inc., 78 F.R.D. 663, 669 (W.D. Pa. 1978) (describing Rule 32(a)(4) as "substantially a restatement" of Federal Rule of Evidence 106 "pertaining specifically to deposition use at trial").

131 FeD. R. Civ. P. 32(a)(6); Guthrie v. Ball, No. 1:11-cv-333-SKL, 2014 U.S. Dist. LEXIS 143175, at*7, 2014 WL 5023096, at*3 (E.D. Tenn. Oct. 8, 2014); Trepel v. Roadway Express, Inc., 194 F.3d 708, 718-19 (6th Cir. 1999).

132 Allgeier v. United States, 909 F.2d 869, 876 (6th Cir. 1990).

133 Prince Lionheart, Inc. v. Halo Innovations, Inc., No. 06-cv-00324-WDM-KLM, 2007 U.S. Dist. LEXIS 77157, at *3-5, 2007 WL 2935818, at*1-2 (D. Colo. Oct. 5, 2007) (collecting cases).

134 Niver v. Travelers Indem. Co., 430 F. Supp. 2d 852, 863 (N.D. Iowa 2006) (quoting Henkel v. XIM Prods., Inc., 133 F.R.D. 556, 557 (D. Minn. 1991)). Some states' rules do recognize a difference between discovery and trial depositions. See Fowler v. Bossano, 010357 (La. App. 3 Cir. 10/03/01); 797 So. 2d 160.

135 FeD. R. CiV. P. 30(c)(2); Brincko v. Rio Props., 278 F.R.D. 576, 580 (D. Nev. 2011); Craig v. St. Anthony's Med. Ctr., 384 F. App'x 531, 532 (8th Cir. 2010). The language now in Rule 30(c)(2) originally appeared in Rule 30(d). Gregory A. Ruehlmann, Jr., Note, "A Deposition is Not a Take Home Examination": Fixing Federal Rule 30(e) and Policing the Errata Sheet, 106 Nw. U. L. REv. 893, 921 (2012); see also Dravo Corp. v. Liberty Mut. Ins. Co., 164 F.R.D. 70,74 (D. Neb. 1995) (citing standard when it appeared in Rule 30(d)(1)). 
reinforced by lawyers' anticipated professionalism and collegiality ${ }^{136}$ and "the general rule that counsel should not engage in any conduct during a deposition that would not be allowed in the presence of a judicial officer." 137 Adopted in $1993,{ }^{138}$ this addition targeted "the number of interruptions during depositions," 139 most especially "unwarranted, lengthy speaking objections." ${ }^{140}$ Heeding the import of this emendation, ${ }^{141}$ courts now disallow a witness' own counsel from interpreting a question

136 See supra notes 2, 9; see also Ethicon Endo-Surgery v. U.S. Surgical Corp., 160 F.R.D. 98, 99 (S.D. Ohio 1995); ThE SEDONA CONFERENCE, supra note 7, at 1; W. Bradley Wendel, Rediscovering Discovery Ethics, 79 MARQ. L. REV. 895, 913, 938 (1996) (defending the existence of a good faith ethical obligation for purposes of discovery). As literature exhaustively suggests, history has arguably shown otherwise. See Wayne D. Brazil, The Adversary Character of Civil Discovery: A Critique and Proposals for Change, 31 VAND. L. REV. 1295, 1298-1300 (1978) (discussing the drafters' original hopes and misconceptions). Some have criticized this notion despite its possible positive effects for "fail[ing] to accord proper weight to lawyers' client-centered obligations and, as a result, may unduly compromise their ability to advocate zealously and effectively on behalf of clients." Brown, supra note 46, at 360. Even this critic, however, recognized that "the officer-of-the-court label serves as a laudable reminder that lawyers' professional responsibility encompasses more than myopic adherence to the interests of clients and the zealous pursuit of their adversarial objectives." $I d$. at 370 .

137 FED. R. Civ. P. 30(d) advisory committee's note to 1993 amendment; Damaj v. Farmers Ins. Co., Inc., 164 F.R.D. 559, 560 (N.D. Okla. 1995). Still, at a deposition, "there is no judge there to rule on objections or admissibility and others may not be precluded from sitting in on the deposition." In re Stratosphere Corp. Secs. Litig., 182 F.R.D. 614, 620 (D. Nev. 1998); see also, e.g., United States v. Kattar, 191 F.R.D. 33, 37 (D.N.H. 1999) (citing In re Stratosphere Corp. Secs. Litig., 182 F.R.D. at 620, and Odone v. Croda Int'1 PLC, 170 F.R.D. 66, 67 (D.D.C. 1997)).

138 FED. R. CIV. P. 30(d) advisory committee's note to 1993 amendment.

139 Plaisted v. Geisinger Med. Ctr., 210 F.R.D. 527, 532 (M.D. Pa. 2002).

140 Offshore Marine Contractors, Inc. v. Palm Energy Offshore, L.L.C., No. 10-4151 Section "R" (3), 2013 U.S. Dist. LEXIS 50299, at *10, 2013 WL 1412197, at *4 (E.D. La. Apr. 8, 2013); see also United States v. Kattar, 191 F.R.D. 33 (D.N.H. 1999) (citing Damaj, 164 F.R.D. at 560 (internal quotation marks omitted)); Diana S. Donaldson, Deposition Essentials: New Basics for Old Masters, LiTIG., Summer 2000, at 28 ("The 1993 revisions to Rule 30(d) were aimed at correcting the abuse of speaking objections by the defending lawyers."). A witness leaves himself or herself liable for non-responsive or evasive narratives or impertinent statements. FED. R. CIV. P. 37; see generally, e.g., Dowdle v. MSE Constr., No. 13-498 Sec. "C" (2), 2014 U.S. Dist. LEXIS 90231, 2014 WL 2992732 (E.D. La. July 2, 2014); Rapaport v. Soffer, No. 2:10-cv-935-MMD-RJJ, 2012 U.S. Dist. LEXIS 183156, 2012 WL 6799742 (D. Nev. Dec. 31, 2012); GMAC Bank v. HTFC Corp., 248 F.R.D. 182 (E.D. Pa. 2008).

141 See, e.g., Donaldson, supra note 140, at 28 ("Litigators are expected to monitor the deposition of their clients and other critical witnesses without acting like advocates."); Beckerman, supra note 8, at 522 ("[T] the extent that success in litigation depends on strategic informational advantage, discovery, contrary to its inventors' expectations, is the critical battlefield on which the war is waged."); Schwarzer, supra note 2, at 713 (contending that the Rules "have left it entirely to the bar to reconcile their adversarial habits with the implicit obligations of candor and cooperation, dealing only with sanctionable excesses under Rules 11, 26, and 37'). 
or aiding his or her client in the midst of another's examination, ${ }^{142}$ and "[s]peaking," "coaching," or "suggestive" objections are categorically banned during federal depositions. ${ }^{143}$ As such, by reason of its concise, non-argumentative, and non-suggestive requirements, added to Rule 30 precisely so as to end a seeming deluge of toxic interruptions, ${ }^{144}$ Rule $30(c)(2)^{145}$ broadly proscribes "obstructive tactics that unreasonably prolong a deposition." 146 Defiance, in turn, triggers Rule 30(d)(2), which authorizes the imposition of "an[y] appropriate sanction . . . on a person who impedes, delays, or frustrates the fair examination of the

142 Hall v. Clifton Precision, 150 F.R.D. 525, 528 (E.D. Pa. 1993); see also, e.g., Heriaud v. Ryder Transp. Servs., No. 03 C 0289, 2005 U.S. Dist. LEXIS 19378, at*4-23, 2005 WL 2230199, at *2-9 (N.D. Ill. Sept. 8, 2005) (documenting repeated instances of hostile conduct by deponent's counsel); In re Stratosphere Corp. Secs. Litig., 182 F.R.D. at 621 (quoting Hall, if nonetheless agreeing with the premise that "that a questioning attorney is entitled to have the witness, and the witness alone, answer questions," the interrogating counsel holding "the right to the deponent's answers, not an attorney's answers"); ARP v. Amezaga (In re Amezaga), 195 B.R. 221, 228 (Bankr. D.P.R. 1996) (admonishing counsel for "extensive and unnecessary colloquy, asserted groundless objections, improperly objected and took every opportunity to interrupt and argue with opposing counsel" in violation of the "limited role" assigned to deponent's counsel by the Rules).

143 McDonough v. Keniston, 188 F.R.D. 22, 24 (D.N.H. 1998); see also, e.g., In re Neurontin Antitrust Litig., MDL No. 1479, 2011 U.S. Dist. LEXIS 6977, at *40, 2011 WL 253434, at *12 (D.N.J. Jan. 25, 2011) (forbidding counsel from making "speaking, coaching or suggestive objections," "making constant objections and unnecessary remarks," or "stat[ing] that counsel does not understand the question"); Quantachrome Corp. v. Micromeritics Instrument Corp., 189 F.R.D. 697, 700 (S.D. Fla. 1999) (reprimanding counsel for making "speaking objections which amounted to providing the witness with counsel's preferred answer to the question," as "the witness must be allowed to provide an answer to the best of his ability, free from any influence by his counsel"); Armstrong v. Hussmann Corp., 163 F.R.D. 299, 303 (E.D. Mo. 1995) ("Attorneys are also prohibited from acting as an intermediary during their client's deposition.").

144 Cary, supra note 52, at 583-84 (discussing FED. R. CIV. P. 30 advisory committee's note to 1993 amendment); $c f$. Byron C. Keeling, A Prescription for Healing the Crisis in Professionalism: Shifting the Burden of Enforcing Professional Standards of Conduct, 25 TEX. TECH L. REV. 31, 36-37 (1993).

145 FED. R. Civ. P. 30(c)(2); Garner v. Mohave Cnty., No. CV-15-08147-PCT-PGR, 2016 U.S. Dist. LEXIS 12530, at*3, 2016 WL 363653, at*1 (D. Ariz. Jan. 29, 2016) (ordering counsel to "limit their deposition objections to concise, nonargumentative, and nonsuggestive statements, as required by" Rule 30).

146 FED. R. CIV. P. 30(d) advisory committee's note to 1993 amendment; United States v. Elsass, No. 2:10-CV-336, 2012 U.S. Dist. LEXIS 66108, at *11, 2012 WL 1658921, at *4 (S.D. Ohio May 11, 2012); see also, e.g., Cary, supra note 52, at 588-93 (discussing the remedies available for the punishment of verbal attacks on clients, deponents, and other attorneys during depositions); Eugene A. Cook, Professionalism and the Practice of Law, 23 TEX. TECH L. REV. 955, 973 (1992) (disparaging litigators who asked the opposing attorney to define such words as "when," "where," "own," and "describe"). If the obstructing counsel truly finds the deposition abhorrent, he or she may resort to Rule 30(d)(3) - and hope a court agrees. FED. R. CIV. P. 30(d)(3) (specifying the circumstances when a motion to terminate a deposition may be made). 
deponent," ${ }^{147}$ a punitive right simultaneously secured by other rules ${ }^{148}$ and laws. ${ }^{149}$

Having specified how an objection must be expressed, Rule 32(b) and (d) limns the consequences of a lawyer's silent acquiescence to defects in manner, form, and more. Pursuant to Rule 32(b), though subject to the parameters erected by Rules 28(b) and 32(d)(3), "an objection may be made at a hearing or trial to the admission of any deposition testimony that would be inadmissible if the witness were present and testifying." ${ }^{150}$ To "an error or irregularity in a deposition notice," failure to serve the objection "promptly" and "in writing on the party giving notice" effects a waiver. ${ }^{151}$ If a party wishes to object to an officer's qualifications, the objection must be made "before the deposition begins" or "promptly after the basis for disqualification becomes known or, with reasonable diligence, could have been known." 152 Waiver of a type of administrative objection - "to how the officer transcribed the testimony ... or prepared, signed, certified, sealed, endorsed, sent, or otherwise dealt with the deposition"-will occur "unless a motion to suppress is made promptly after the error or irregularity becomes known or, with reasonable diligence, could have been known."153

Rule 32(d)(3) deals with more substantive objections related to a deposition's undertaking. ${ }^{154}$ Waiver of an objection to an "error or irregularity at an oral examination" under Rule 30 ensues so long as it is "not timely made during the deposition" and it falls within one of four categories: (1) "the manner of taking the deposition"; (2) "the form of a

147 Fed. R. Civ. P. 30(d)(2); Ryan v. Astra Tech, Inc., 772 F.3d 50, 56 (1st Cir. 2014).

148 Fed. R. Civ. P. 37(b); Gratton v. Great Am. Commc'ns, 178 F.3d 1373, 1374 (11th Cir. 1999) ("Rule 37 sanctions are intended to prevent unfair prejudice to the litigants and insure the integrity of the discovery process.").

149 Carlucci v. Piper Aircraft Corp., 775 F.2d 1440, 1446 (11th Cir. 1985) ("[A]11 federal courts have the power, by statute, by rule, and by common law, to impose sanctions against recalcitrant lawyers and parties litigant." (citing Rule 37 and 28 U.S.C. $§ 1927$ (1985))).

150 FeD. R. Civ. P. 32(b); Henderson v. Turner, No. 11-39 Section "C" (4), 2012 U.S. Dist. LEXIS 106630, at*2, 2012 WL 3109481, at*1 (M.D. La. July 31, 2012).

151 FeD. R. CIV. P. 32(d)(1); Woods v. Deangelo Marine Exhaust Inc., No. 08-81579Civ-Hurley/Hopkins, 2010 U.S. Dist. LEXIS 110293, at*13, 2010 WL 4116571, at *4 (S.D. Fla. Sept. 27, 2010).

152 Fed. R. Civ. P. 32(d)(2)(A)-(B); Allen v. Figuera, 416 F. App'x 771, 775 n.6 (10th Cir. 2011). Rule 28 establishes the minimal requirements for the persons before whom depositions may be taken within and without the United States. FED. R. CIV. P. 28(b); Mujica v. Occidental Petroleum Corp., 381 F. Supp. 2d 1134, 1151 (C.D. Cal. 2005); Zassenhaus v. Evening Star Newspaper Co., 404 F.2d 1361, 1362 n.1 (D.C. Cir. 1968).

153 Fed. R. CIV. P. 32(d)(4); Taylor v. Oak Forest Health \& Rehab., LLC, 302 F.R.D. 390, 396 (M.D.N.C. 2014).

154 FED. R. CIV. P. 32(d)(3); United States v. Kearney, 560 F.2d 1358, 1364 n.6 (9th Cir. 1977). 
question or answer, the oath or affirmation"; (3) "a party's conduct"; or (4) "other matters that might have been corrected at that time." 155 A caveat as to waiver's application appears in Rule 32(d)(3)(A) regarding an objection to "[a] deponent's competence" or "the competence, relevance, or materiality of testimony", ${ }^{156}$ generally, such a protest "is not waived by a failure to make the objection before or during the deposition, unless the ground for it might have been corrected at that time." 157 An objection to the form of a question posed during a written deposition leads to a waiver "if not served in writing on the party submitting the question within the time for serving responsive questions or, if the question is a recrossquestion, within 7 days after being served with it." 158

\section{B. Case Law: Simple Form Objections versus Precise Form Objections}

Within the "misshapen body of rules that only conflicting principles could create," 159 two incompatible views regarding form objections have gained adherents. Neither side has yet attained primacy, with courts uninclined to punish behavior permitted by others. ${ }^{160}$ As the perusal of a handful of representative decisions reveals, upon the essential meaning of Rule 30(c)(2)'s second sentence-"'An objection must be stated concisely in a nonargumentative and nonsuggestive manner" ${ }^{\prime 161}$ — and the mischief sought to be addressed by this clause--"Depositions frequently have been unduly prolonged, if not unfairly frustrated, by lengthy objections and

155 FeD. R. CiV. P. 32(d)(3)(B); Kan. Wastewater, Inc. v. Alliant Techsystems, Inc., 217 F.R.D. 525, 528 (D. Kan. 2003); Oberlin v. Marlin Am. Corp., 596 F.2d 1322, 1328 (7th Cir. 1979); Houser v. Snap-on Tools Corp., 202 F. Supp. 181, 188 (D. Md. 1962).

156 Fed. R. CIV. P. 32(d)(3)(A); America's Collectibles Network, Inc. v. MIG Broad. Grp., Inc., 330 F. App'x 81, 91-92 (6th Cir. 2009).

157 FeD. R. Civ. P. 32(d)(3)(A) (emphasis added); Bonds v. Padlock, No. 06-7830 Section J(5), 2008 U.S. Dist. LEXIS 96098, at*6, 2008 WL 4889794, at*2 (E.D. La. Nov. 10, 2008).

158 FED. R. CIV. P. 32(d)(3)(C).

159 James W. McElhaney, Objecting at Depositions, LiTig., Summer 1988, at 52.

160 The judiciary apparent reluctance to sanction even universally condemned conduct has frustrated many. See, e.g., Beisner, supra note 8, at 552; Beckerman, supra note 8, at $511,518,574$. Regardless, the standard for such sanctions is generally viewed as rather high. For example, though the Rules "place virtually no limits on judicial creativity with respect to sanctions imposed under Rule 37 . . . a higher standard of due process protection is required where ... the sanction is a fine designed to go beyond compensation and punish an attorney." Bonilla v. Trebol Motors Corp., No. 92-1795 (JP), 1997 U.S. Dist. LEXIS 4370, at *22-23, 1997 WL 178844, at*7-8 (D.P.R Mar. 27, 1997) (citing Jaen v. CocaCola Co., 157 F.R.D. 146, 149 (D.P.R. 1994), and Media Duplication Servs., Ltd. v. HDG Software, Inc., 928 F.2d 1228, 1238 (1st Cir. 1991)), rev'd, 150 F.3d 88, $93-94$ (1st Cir. 1998).

161 FED. R. CIV. P. 30(c)(2); Synventive Molding Solutions, Inc. v. Husky Injection Molding Sys., 262 F.R.D. 365, 375 (D. Vt. 2009). 
colloquy, often suggesting how the deponent should respond"162 - have these warring sides fixated.

Ably representing one faction, objecting counsel must "say simply the word 'objection,' and no more," one court ordered, "to preserve all objections as to form." 163 A particular apperception, premised on three interconnected notions, lay behind this strict attitude. First, counsel should "deal fairly and sincerely with the court and opposing counsel so as to conserve the time and expense of all, and that actions may be litigated in an orderly manner"; 164 as to discovery, counsel is bound to honor the Rules" "implicit obligations of candor and cooperation." 165 Second, even a proper objection, if packed too full, inevitably "interfere[s] with the deposing attorney's pursuit of the truth and allow[s] the witness's attorney to suggest answers." 166 If discovery is to be relatively economical, attorneys should be prevented from "mak[ing] any comments, either on or off the record . . . which might suggest or limit a witness'[] answer,"167 and an objection should no more than "succinctly and simply state the legal basis for the objection, with no additional commentary." "168 Instead of disrupting another's questioning, counsel should "rely on the court to rule upon the objections if the parties use the deposition in later proceeding" and not impede the deposition entire ${ }^{169}$ by means of lengthy soliloquies, ${ }^{170}$ "sanctionable excesses" subject to "Rules 11, 26, and 37." ${ }^{171}$ Third, discerning clarity in a muddled area, ${ }^{172}$ this juridical multitude has insisted that "form" delivers "sufficient explanation to notify the interrogator of the ground for the objection, and thereby allow

162 FED. R. CIV. P. 30(d) advisory committee's note to 1993 amendment.

163 In re St. Jude Med., Inc., Silzone Heart Valves Prods. Liab. Litig., MDL No. 1396, 2002 U.S. Dist. LEXIS 28020, at*13, 2002 WL 1050311, at*5 (D. Minn. May 24, 2002).

164 Morales v. Zondo, Inc., 204 F.R.D. 50,57 (S.D.N.Y. 2001) (quoting Learning Int'1 Inc. v. Competence Assurance Sys., No. 90 Civ. 2032 (MBM), 1990 U.S. Dist. LEXIS 16810, at *8-9, 1990 WL 204163, at*3 (S.D.N.Y. 1990)).

165 Schwarzer, supra note 2, at 713.

166 Cordova v. United States, No. CIV 05-563 JB/LFG, 2006 U.S. Dist. LEXIS 98226, at *10, 2006 WL 4109659, at*4 (D.N.M. July 31, 2006).

167 Armstrong v. Hussmann Corp., 163 F.R.D. 299, 303 (E.D. Mo. 1995).

168 Craig v. St. Anthony's Med. Ctr., No. 4:08CV00492 ERW, 2009 U.S. Dist. LEXIS 19909, at *7, 2009 WL 690210, at *2 (E.D. Mo. Mar. 12, 2009); see also Specht v. Google, Inc., 268 F.R.D. 596, 598 (N.D. Ill. 2010) ("[A] party who wishes to object to a question must do so concisely, and the deponent must still answer the question.").

169 J.C. v. Soc'y of Jesus, Or. Prov., No. C05-1662JLR, 2006 U.S. Dist. LEXIS 78584, at $* 20,2006$ WL 3158814, at *6 (W.D. Wash. Oct. 27, 2006).

170 State Farm Mut. Auto. Ins. Co. v. Tabakman, No. 06-CV-2896 (SLT) (JMA), 2008

U.S. Dist. LEXIS 77784, at*4, 2008 WL 4527731, at *2 (E.D.N.Y. Oct. 3, 2008).

171 Schwarzer, supra note 2, at 713.

172 See infra Part III. 
revision of the question." 173 As cumulatively weighed by this panoply of courts and scholars, these assumptions compel one decision regarding the requisite content of a form objection: because "form" suffices to make an objection "concise[]," Rule 30(c)(2) puts forward the simple form objection as a requirement and an ideal, ${ }^{174}$ an embargo codified in some districts' local rules. ${ }^{175}$

Others have rejected this straitened reading, resting on other presumptions. ${ }^{176}$ First, whenever "an objector . . . state[s] in a few words the manner in which the question is defective as to form (e.g., compound, vague as to time, misstates the record, etc.)," the questioner is "alert[ed] ... to the alleged defect" and "afford[ed] an opportunity to cure the objection." 177 Second, "[g]iven that "form' may refer to any number

173 Applied Telematics v. Sprint Corp., No. 94-CV-4603, 1995 U.S. Dist. LEXIS 2191, at *4, 1995 WL 79237, at*1 (E.D. Pa. Feb. 22, 1995); $f$. LeClair v. Napoli Grp., LLC, No. 2:10-CV-28, 2011 U.S. Dist. LEXIS 67675, at*13, 2011 WL 2517228, at *4 (D. Vt. June 23, 2011) ("[W]here Counsel objects to the form of a question and then instructs the deponent to answer there is no affirmative obligation to further explain the objection." (emphasis added)).

174 See, e.g., Offshore Marine Contractors, Inc. v. Palm Energy Offshore, L.L.C., No. Civ. A 10-4151 Section "R" (3), 2013 U.S. Dist. LEXIS 50299, at*10, 2013 WL 1412197, at *4 (E.D. La. Apr. 8, 2013) ("The Court finds that the behavior of counsel for OMC does not warrant sanctions here," as "most of the objections by OMC's counsel are simple form objections with no unwarranted, lengthy speaking objections."); Fed. Hous. Fin. Agency v. UBS Ams., Inc., No. 11 Civ. 5201 (DLC), 2012 U.S. Dist. LEXIS 190502, at *85, 2012 WL 5954817, at *5 (S.D.N.Y. Nov. 28, 2012) ("Counsel will limit their objections to 'Objection, Form,' 'Objection, Foundation,' 'Objection, Responsiveness,' or 'Objection, Beyond Scope,' and such objections will be sufficient to preserve all relevant objections.”); Cordova v. United States, No. CIV 05-563 JB/LFG, 2006 U.S. Dist. LEXIS 98226, at *56, 2006 WL 4109659, at *2 (D.N.M. July 31, 2006) (explaining that only if "[i]f counsel objects to a question at deposition based on the form of the question, counsel may briefly explain the objection if the deposing counsel asks for an explanation and counsel does not in the explanation suggest an answer to the deponent" (emphasis added)); Druck Corp. v. Macro Fund (U.S.) Ltd., No. 02 Civ. 6164, 2005 U.S. Dist. LEXIS 16721, at *12, 2005 WL 1949519, at *4 (S.D.N.Y. Aug. 12, 2005) ("Any "objection as to form" must say only those four words, unless the questioner asks the objector to state a reason." (emphasis added)); Auscape Int'l v. Nat'l Geographic Soc'y, No. 02 Civ. 6441 (LAK), 2002 U.S. Dist. LEXIS 16675, at *2, 2002 WL 31014829, at*1 (S.D.N.Y. Sept. 6, 2002) ("Once counsel representing any party states, 'Objection' following a question, then all parties have preserved all possible objections to the form of the question.").

175 Mass Engineered Design, Inc. v. Ergotron, No. 206 CV 272, 2008 U.S. Dist. LEXIS 123347 , at *14, 2008 WL 8667511, at*1 (E.D. Tex. Jan. 8, 2008) ("Unless permitted by FED. R. Civ. P. 30(d)(1), a party may not instruct a deponent not to answer a question. Objections to questions during the oral deposition are limited to 'Objection, leading' and 'Objection, form.'” (quoting E.D. TEX. CIV. R. 30))); accord Turner v. Glock, Inc., No. 1:02cv825, 2004 WL 5511620, at*1 (E.D. Tex. Mar. 29, 2004).

176 Rakes v. Life Investors Ins. Co. of Am., No. C06-0099, 2008 U.S. Dist. LEXIS 10996, at*16, 2008 WL 429060, at*5 (N.D. Iowa Feb. 14, 2008).

177 Id. (characterizing this process as "the general practice in Iowa"); accord Sec. Nat'l Bank of Sioux City, Iowa v. Abbott Labs., 299 F.R.D. 595, 601, 602 (N.D. Iowa 2014), rev'd, 800 F.3d 936 (8th Cir. 2015); see also Cincinnati Ins. Co. v. Serrano, No. 11-2075- 
of objections, saying 'form' to challenge a leading objection is as useful as saying "exception' to an excited utterance." 178 In view of this inexpiable ambiguity, the pithy "form" cannot aid the examiner in rectifying a certain enquiry's improper structure in the most efficient and direct of manners, too likely to induce wasteful rumination over any and all possible glitches and what corrections, if any, are in order in response to an expressly unidentified deficiency. ${ }^{179}$ Responding to these concerns, to this camp, an objection can only be "succinct and economical," as Rule 30(c)(2) requires, when it instantaneously discloses its "basis." 180 In contrast, the perfunctory interjection of the talismanic "form" "181 increases opacity and raises the odds of undue delay in discovery's completion and, with it, a case's just and speedy termination. So convinced, this scholarly and judicial mass contends that precise form objections do not contravene Rule 30 's bare text and accord with the Rules' intrinsic spirit, assuming the objector does not surreptitiously "attempt to suggest an answer, or to influence or 'coach' the witness" in the same breath. ${ }^{182}$

Noticing this divide, more than a few opinions have acknowledged the confusion over the right style for form objections generated by Rule 30(c)(2)'s second sentence. ${ }^{183}$ One court, for instance, recently refused to sanction form objections it deemed improper; despite its chagrin and conviction, it was unable to disregard the sanctuary offered to defendant's position by a handful of contrary opinions wholly ignored by the parties. ${ }^{184}$ Yet another found Rule 30(c)(2) to require precise form objections, but it paradoxically endeavored to incentivize compliance with a requirement it

JAR, 2012 US Dist. LEXIS 1363, at*12-13, 2012 WL 28071, at*5 (D. Kan. Jan. 5, 2012) (expressing its expectation that "that it would be adequate if the question's defect was in ... [the] broad category [of form] and if the deposing party failed to request a clarification at the deposition").

178 Abbott Labs., 299 F.R.D. at 601; see also infra Part III.

179 Abbott Labs., 299 F.R.D. at 601-02.

180 Birdline v. City of Coatesville, 225 F.R.D. 157, 158 (E.D. Pa. 2004) (describing Hall v. Clifton Precision, 150 F.R.D. 525 (E.D. Pa. 1993), as "thoughtful and instructive" but as "go[ing] too far in forbidding an attorney who defends a deposition . . . from making most objections and from instructing the witness not to answer an objectionable question"). Hall, the lodestar case within the strictest camp, is "controversial due to its strictness, and it is not followed in all jurisdictions." Dickerson, supra note 42, at 292.

181 Cf. Damgaard v. Avera Health, No. 13-2192 (RHK/JSM), 2015 U.S. Dist. LEXIS 46997, at *23-27, 2015 WL 1608209, at*8-10 (D. Minn. Apr. 10, 2015) (finding no basis for striking deposition due to counsel's explanatory objections). Staking out an extreme position, one such inclined jurist has maintained that Rule 30(c)(2), read in conjunction with Rule 32(d)(3), actually "require[s]" lawyers to "state the basis for their objections." Abbott Labs., 299 F.R.D. at 602 (emphasis in original).

182 Rakes, 2008 U.S. Dist. LEXIS 10996, at*16, 2008 WL 429060, at*5.

183 Cohen v. Trump, No. 13-CV-02519-GPC (WVG), 2015 U.S. Dist. LEXIS 65471, at *5-6 \& n.1, 2015 WL 2406094, at *2 \& n.1 (S.D. Cal. May 19, 2015).

184 Abbott Labs., 299 F.R.D. at 603. 
had just construed as mandatory and unambiguous. ${ }^{185}$ In explicating guidelines employing the identical phrasing embedded in Rule 32(d)(3)(B), ${ }^{186}$ a third court made several trenchant observations. "[T]he Guidelines talk about objections based on the 'form' of a question," it admitted; such talk implies a prohibition on any more substantive commentary. ${ }^{187}$ But such an implication does not automatically follow, it continued, and this interdict is thus not inevitably violated when an objection "briefly specif[ies] the nature of the form objection (e.g., 'compound,' leading,' 'assume facts not in evidence')." 188 Uncertain, this court vouchsafed no "definitive opinion" as to whether the germane guideline permitted, much less endorsed, anything but a simple form objection. ${ }^{189}$

\section{SOURCES OF CONFUSION}

I would just object to the form of the question.

As I read this, I can't be certain as to what exactly she's

referring to at what point here... .

Objection; calls for a legal conclusion, vague and ambiguous as

to what 'harm' is.

I'm not sure how to answer that question.

Yes or no would work."

I'm not sure how to answer that question.

Were you harmed by what they were doing-

What do you mean 'harmed'? Harmed in what way are you

\footnotetext{
185 Auscape Int'l v. Nat'l Geographic Society, No. 02 Civ. 6441 (LAK), 2002 U.S. Dist. LEXIS 16675, at*2, 2002 WL 1050311, *1 (S.D.N.Y. Sept. 6, 2002).

186 Compare FED. R. Civ. P. 32(d)(3)(B) (“form of a question or answer"), with D. KAN. DEPOSITION GUIDELINES $\uparrow$ 5(a) ("Objections shall be concise and shall not suggest answers to or otherwise coach the deponent.").

187 Cincinnati Ins. Co. v. Edward Serrano, No. 11-2075-JAR, 2012 US Dist. LEXIS 1363, at*12, 2012 WL 28071, at*5 (D. Kan. Jan. 5, 2012).

188 Id.

189 Id.; $c f$. Gerber Sci. Int'1, Inc. v. Roland DGA Corp., No. 3:06-cv-2024, 2010 U.S. Dist. LEXIS 97936, at*10, 2010 WL 3803206, at*3 (D. Conn. Sept. 20, 2010) (describing counsel's objections, which "seemed to merely state the reasons for his placing the objection on the record," as "longer than the rules suggest"). Anticipating trouble, other courts have urged parties to enter into stipulations preserving any and all possible objections as to form. Mendez v. R+L Carriers, Inc., No. CV 11-02478-CW (JSC), 2012 U.S. Dist. LEXIS 60148, at *6, 2012 WL 1535756, at*2 (N.D. Cal. Apr. 30, 2012).
} 
asking me?

I'm - I'm - I'm glad to hear that [c] ounsel's coaching is

effective.

\section{A. Elastic Definition of "Form"}

In legal discourse, the term "form" denotes "a category" 190 into which at least twelve common objections fall: (1) ambiguous, vague, or unintelligible; (2) argumentative; (3) compound; (4) leading; (5) mischaracterizes or misquotes the witness' prior testimony or misstates the record; (6) calls for a narrative; (7) calls for speculation; (8) asked and answered; (9) assumes facts not in evidence; (10) misleading; (11) lack of personal knowledge; and (12) witness' answers that are beyond the question's scope. ${ }^{191}$ Multiple courts place a lack of foundation in this grouping, ${ }^{192}$ but more than one has characterized such an objection as a relevance one. ${ }^{193}$ A similar divide exists as to an objection that a question is "overbroad," an interruption predicated not on an evidentiary rule, ${ }^{194}$ but

190 Abbott Labs., 299 F.R.D. at 601 (emphasis in original).

191 Henry L. Hecht, EFFECTIVE Depositions 359-62 (1998) (enumerating (1) through (10)); Hernandez v. Creative Concepts, No. 2:10-cv-02132-PMP-VCF, 2013 U.S. Dist. LEXIS 71695, at *5-6, $2013 \mathrm{WL} 2245781$, at *2 (D. Nev. May 21, 2013) (summarizing some of the objections commonly labeled "form"); Jadwin v. Abraham, No. 1:07-cv00026-OWW-TAG, 2008 U.S. Dist. LEXIS 116780, at*13-14, 2008 WL 4057921, at *56 (E.D. Cal. Aug. 22, 2008) (identifying "asked and answered" as a form objection); Rakes v. Life Investors Ins. Co. of Am., No. C06-0099, 2008 U.S. Dist. LEXIS 10996, at*16, 2008 WL 429060, at *5 (N.D. Iowa Feb. 14, 2008) (listing three-_"compound," "vague as to time," and "misstates the record"); St. Luke's Episcopal Hosp. v. Garcia, 928 S.W.2d 307, 309 (Tex. Ct. App. 1996) (listing ten of the thirteen).

192 See, e.g., Gavrity v. City of New York, No. 12-CV-6004 (KAM) (VMS), 2014 U.S. Dist. LEXIS 132035, at *23 n.5, 2014 WL 4678027, at *7 n.5 (E.D.N.Y. Sept. 19, 2014); NGM Ins. Co. v. Walker Constr. \& Dev. LLC, No. 1:11-CV-146, 2012 U.S. Dist. LEXIS 177161, at *7, 2012 WL 6553272, at *2 (E.D. Tenn. Dec. 13, 2012); Abu Dhabi Commercial Bank v. Morgan Stanley \& Co., No. 08 Civ. 7508 (SAS), 2011 U.S. Dist. LEXIS 116840, at *27 \& n.35, 2011 WL 4526141, at *8 \& n.35 (S.D.N.Y. Sept. 21, 2011) (citing Boyd v. Univ. of Md. Med. Sys., 173 F.R.D. 143, 147 n. 8 (D. Md. 1997))). At least two of these cases appear to misconstrue another, which classified a foundation objection as one "which could have been cured at the time of the deposition and/or relate[s] to the form of the question or answer." Harper v. Griggs, No. 04-260-C, 2007 U.S. Dist. LEXIS 10395, at *4 \& n.1, 2007 WL 486726, at*1 \& n.1 (W.D. Ky. Feb. 12, 2007) (emphasis added).

193 See, e.g., Cincinnati Ins. Co., 2012 U.S. Dist. LEXIS 1363, at*11, 2012 WL 28071, at *4; $c f$. AMCO Ins. Co. v. Madera Quality Nut LLC, No. 1:04-cv-06456-SMS, 2006 U.S. Dist. LEXIS 101238, at*19, 2006 WL 2091944, at*6 (E.D. Cal. July 26, 2006) (observing that an objection for a lack of foundation is sometimes "accompanied by a relevance objection or from context appears to be based on an absence of authentication").

194 From the Federal Rules of Evidence a handful of form objections can be mined, but far more have been refined in case law. See David J. Langum, Uncodified Federal Evidence 
on Rule 26(b)(1). ${ }^{195}$ Often camouflaged, a "speaking," "coaching," "suggestive," or "argumentative" objection "suggest[s an] answer[] to or otherwise coach[es] the witness." "196 As this persistent ambiguity about the meaning of "form" and the sheer number of such objections suggest, in the absence of any elaboration, a complaint regarding a question's "form" may often refer to a multiplicity of discrete and otherwise distinguishable defects in a query's initial structure. ${ }^{197}$ In informal practice as well as in formal understanding, "form" is a malleable classification, ${ }^{198}$ its quiddity fixed by neither dictionary nor custom. ${ }^{199}$ This verity makes ready lingual sense, as "the meaning of language is inherently contextual." 200

\section{B. Other Hurdles: Absent Standards and Discretionary Terms}

While this uncertainty invites one set of problems, the Rules' text begets others. As a general matter, while the discovery rules seemingly prioritize the virtue ${ }^{201}$ and the advisory committee's valued ${ }^{202}$ commentary

Rules Applicable to Civil Trials, 19 WiLliameTte L. REV. 513, 516 (1983) (noting that the form objection that a question is leading is covered by Federal Rule of Evidence 611 but that "[m] any other objections as to form . . . are deeply rooted in the general common law and case authority, but are not mentioned in the Federal Rules [of Evidence]"); $c f$. Craig Lee Montz, Trial Objections from Beginning to End: The Handbook for Civil and Criminal Trials, 29 PEPP. L. REv. 243, 284-97 (2002) (listing some common "form" objections). A brief explanation for this dearth appears in the advisory committee's note: "Spelling out detailed rules to govern the mode and order of interrogating witnesses and presenting evidence is neither desirable nor feasible." FED. R. EvID. 611 advisory committee's note.

195 Cincinnati Ins. Co., 2012 U.S. Dist. LEXIS 1363, at*13, 2012 WL 28071, at *5. But see Sec. Nat'l Bank of Sioux City v. Abbott Labs., 299 F.R.D. 595, 601-03 (N.D. Iowa 2014), rev'd, 800 F.3d 936 (8th Cir. 2015).

196 Cincinnati Ins. Co., 2012 U.S. Dist. LEXIS 1363, at*10-11, 2012 WL 28071, at *4; $c f$. Deville v. Givuadan Fragrances Corp., No. 08-2034 (GEB-MCA), 2010 U.S. Dist. LEXIS 53186, at*19-24, 2010 WL 2232718, at *6-8 (D.N.J. June 1, 2010) (summarizing magistrate judge's reasons for finding the "suggestive and argumentative speaking objections" of plaintiff's counsel); AG Equip. Co. v. AIG Life Ins. Co., No. 07-CV-556CVE-PJC, 2008 U.S. Dist. LEXIS 99915, at*6-7, 2008 WL 5205192, at*2 (N.D. Okla. Dec. 10, 2008) (defining "speaking objections" as suggestive and frequent).

197 Abbott Labs., 299 F.R.D. at 601.

198 See Mayor \& City Council of Baltimore v. Theiss, 729 A.2d 965, 976 (Md. 1999); accord Abbott Labs., 299 F.R.D. at 603 ("When called upon to rule on an unspecified 'form' objection, a judge either must be clairvoyant or must guess as to the objection's basis. Neither option is particularly realistic or satisfying.").

199 See Rakes v. Life Investors Ins. Co. of Am., No. C06-0099, 2008 U.S. Dist. LEXIS 10996, at*16, 2008 WL 429060, at*5 (N.D. Iowa Feb. 14, 2008).

200 Moskal v. United States, 498 U.S. 103, 108, 111 S. Ct. 461, 465, 112 L. Ed. 2d 449, 458 (1990); accord United States v. Dauray, 215 F.3d 257, 264 (2d Cir. 2000); cf. STEVEN Pinker, The Language Instinct: How the Mind Creates Language 57-58 (1994) (discussing language's seemingly inherent imprecision).

201 SEDONA CONFERENCE, supra note 7, at 8.

202 See Tome v. United States, 513 U.S. 150, 167, 115 S. Ct. 696, 706, 130 L. Ed 2d 574,589 (1995) (Scalia, J., concurring in part and concurring in judgment) (describing the explanatory notes prepared by the advisory committees, "a body of experts," as "assuredly 
almost consecrates it, ${ }^{203}$ the requirement of cooperation is entirely absent from the Rules' body text, ${ }^{204}$ despite more than two decades of tinkering. ${ }^{205}$ Complicating any determination of the extent to which a party's obligations is the fact that the relevant rules and commentary ${ }^{206}$ refer to "unreasonabl[e]" conduct and "undue" costs and delay "without giving any clues as to how those conclusory terms should be interpreted."207 Perhaps ineluctably, this dearth has spawned "[c]ases interpreting the rules . . . in a similarly circular fashion," 208 themselves evidence of the delay and expense engendered by equity practice at its most unrestrained. ${ }^{209}$ Third, rooted in the pre-Rules past, the contemporaneous objection rule inlaid in Rule 32 was not (and could not be) enthused with the "fact-gathering" spirit of Rules' deposition procedure. ${ }^{210}$ Rather, as the product of another time, it had been designed as part of a system in which the relevant "inquiry was strictly limited to preserving proof for trial, and not to be used as discovery" and was carried over unchanged into the far more liberal Rules. ${ }^{211}$ However one may try to fit it into the Rules' discovery mechanism, historical happenstance may render such harmonization impossible. ${ }^{212}$ In the ongoing squabble over form objections, these three factors - the atextual mooring of a familiar

persuasive scholarly commentaries-ordinarily the most persuasive-concerning the meaning of the Rules").

203 FED. R. CIV. P. 30 advisory committee's note to 1993 amendment; see also FED. R. CIV. P. 1 advisory committee's note to 2015 amendment ("Effective advocacy is consistent with - and indeed depends upon - cooperative and proportional use of procedure.").

204 Grimm \& Yellin, supra note 8, at 525. It appears but once in Title V: Rule 37 is entitled "Failure to Make Disclosures or to Cooperate in Discovery; Sanctions." FED. R. CIV. P. 37.

205 See, e.g., FED. R. CIV. P. 26 advisory committee's note to 1983 amendment; Marcus, supra note 55, at 748-50, 752-53 (discussing a number of proposed reforms, some of which were eventually adopted).

206 FED. R. CIV. P. 26(b), 30(d)(3)(A); FED. R. Civ. P. 30 advisory committee's note to 1993 amendment.

207 Wendel, supra note 136, at 896.

208 Id.; cf. Steven W. Rhodes, Eight Statutory Causes of Delay and Expense in Chapter 11 Bankruptcy Cases, 67 AM. BANKR. L.J. 287, 294 (1993) (characterizing "cause" and "reasonable" as two of the many terms in title 11 of the United States Code that imply discretion). Indeed, due to "the coalescence of numerous developments [that] significantly transformed the character of considerable federal civil litigation," federal courts have long wrestled with "many unforeseeable issues for whose resolution the Rules afforded little guidance." Carl Tobias, Public Law Litigation and the Federal Rules of Civil Procedure, 74 CORNELl L. REV. 270, 271 (1989).

209 Subrin, Equity's Conquest, supra note 31, at 934-35. The famed code drafted by David Dudley Field II had targeted such discretion; the Rules rejected Field's tight proscriptions. Id.

210 Moritz, supra note 14, at 1357-58.

211 Id. at 1363.

212 Id. at 1403 (arguing for its elimination from the Rules' fifth title); see also Subrin, Equity's Conquest, supra note 31, at 925-26. 
virtue, the near futility of reducing "undue" or "unreasonable" to graspable standards, and the vestigial quality of the contemporaneous objection rule - complicate the construal of Rules 30 and 32.

\section{A COHERENT INTERPRETATION OF RULES 30 AND 32}

Okay. Objection; badgering. And that second part wasn't a

question, so move to strike. Asked and answered. Go ahead and

answer one more time if you know. The next time I'm going to

instruct you not to answer....

Objection; asked and answered. You don't need to answer again.

I've already answered the question.

Five different ways and five different times.

Again, coaching and obstructionism.

\section{A. Relevant Principles}

With a federal rule, interpretation begins with its written terms, ${ }^{213}$ the text's plain and unambiguous meaning ${ }^{214}$ controlling subject to at least five exceptions. $^{215}$ Averred so absolutely and reflexively, this dominant approach's emphasis on "plain meaning" can obscure one of its more critical components. Namely, "specific" and "general" context, perpetually informed by the relevant provision's obvious and well-known purposes, ${ }^{216}$ will often determine the extent to which any word or phrase

213 Pavelic \& LeFlore v. Marvel Entm’t Grp., 493 U.S. 120, 123, 110 S. Ct. 456, 458, 107 L. Ed. 2d 438, 443 (1989).

214 Bus. Guides v. Chromatic Commc'ns Enters., 498 U.S. 533, 540-41, 111 S. Ct. 922, 928, 112 L. Ed. 2d 1140, 1152 (1991), superseded by FED. R. CIV. P. 11 (amended 1993); see also, e.g., Pioneer Invs. Servs. Co. v. Brunswick Assocs. Ltd. P'ship, 507 U.S. 380, 388, 113 S. Ct. 1489, 1494-95, 123 L. Ed. 2d 74, 85 (1993); Traylor v. Freeland \& Kronz, 503 U.S. 638, 643-44, 12 S. Ct. 1644, 1648, 118 L. Ed. 2d 280, 287 (1992).

215 A plain meaning will be rejected when an absurd result would follow, clear evidence of contrary intent exists, no plausible purpose would thereby be attained, it represents a scrivener's mishap, or a conflict with the Constitution or substantive law would be engendered. Shachmurove, supra note 23, at 530-31 (summarizing the pertinent principles).

216 See, e.g., Yates v. United States, 135 S. Ct. 1074, 1082, 191 L. Ed. 2d 64, 76-77 (2015) (quoting Atl. Cleaners \& Dyers, Inc. v. United States, 286 U.S. 427, 433, 52 S. Ct. 607, 608-09, 76 L. Ed. 1204, 1207 (1932)); Util. Air Regulatory Grp. v. EPA, 134 S. Ct. 2427, 2442, 189 L. Ed. 2d 372, 392-93 (2014) (quoting United Sav. Assn. of Tex. v. Timbers of Inwood Forest Assocs., Ltd., 484 U.S. 365, 371, 108 S. Ct. 626, 630, 98 L. Ed. 2d 740, 748 (1988)); $c f$. Antonin ScAlia \& Bryan A. Garner, Reading Law: The INTERPRETATION OF LEGAL TEXTS 33 (2012) (contending that "context" embraces not "just 
possesses a single operative meaning, ${ }^{217}$ imbued with one denotation and connotation. ${ }^{218}$ Notably, fidelity to this principle is expected regardless of the harshness of the resulting interpretation's application, ${ }^{219}$ though courts have only inconsistently acquiesced ${ }^{220}$ and though the Rules were drafted

textual purpose but also (1) a word's historical associations acquired from recurrent patterns of past usage, and (2) a word's immediate syntactic setting - that is, the words that surround it in a specific utterance").

217 See, e.g., United States v. Ron Pair Enters., Inc., 489 U.S. 235, 240-41, 109 S. Ct. 1026, 1030, 103 L. Ed. 2d 290, 297-98 (1989); United States v. Alfeche, 942 F.2d 697, 699 (9th Cir. 1991); cf. Moskal v. United States, 498 U.S. 103, 108, 111 S. Ct. 461, 465, 112 L. Ed. 2d 449, 458 (1990).

218 Robinson v. Shell Oil Co., 519 U.S. 337, 341, 117 S. Ct. 843, 846, 136 L. Ed. 2d 808, 813 (1997); see also, e.g., L.S. Starrett Co. v. FERC, 650 F.3d 19, 25 (1st Cir. 2011) ("Where [t]here is no legislative history that illuminates the purpose of a particular statutory term, we are left with language, structure, and evident purpose." (alteration in original) (internal quotation marks omitted)); United States v. Onyeiwu, 108 F. App'x 94, 95 (4th Cir. 2004) (citing Robinson, 519 U.S. at 341); cf. Dole Food Co. v. Patrickson, 538 U.S. 468, 484, 123 S. Ct. 1655, 1665, 155 L. Ed. 2d 643, 658 (2003) (Breyer, J., concurring in part and dissenting in part) ("Statutory interpretation is not a game of blind man's bluff. Judges are free to consider statutory language in light of a statute's basic purposes."). Typically, "[a]mbiguity only exists so long as several plausible interpretations of the same statutory text, specific and different in substance, can be advanced." Stern v. Am. Home Mortg. Servicing, Inc. (In re Asher), 488 B.R. 58, 64 (Bankr. E.D.N.Y. 2013); see also Shachmurove, supra note 23, at 530-34 (discussing the Court's system for interpretation of ambiguous rules); cf. Amir Shachmurove, Sherlock's Admonition: Vindicatory Contempts as Criminal Actions for Purposes of Bankruptcy Code $\$ 362,13$ DePAul Bus. \& CoM. L.J. 67, 74-77 (2014) (explaining the Court's approach to construing ambiguous statutes).

219 See, e.g., Lamie v. U.S. Tr., 540 U.S. 526, 538, 124 S. Ct. 1023, 1032, 157 L. Ed. 2d 1024, 1036 (2004) ("Our unwillingness to soften the import of Congress' chosen words even if we believe the words lead to a harsh outcome is longstanding."); Badaracco v. Comm'r, 464 U.S. 386, 398, 104 S. Ct. 756, 764, 78 L. Ed. 2d 549, 560 (1984) ("Courts are not authorized to rewrite a statute because they might deem its effects susceptible of improvement."); Cent. Trust Co. v. Official Creditors' Comm. of Geiger Enters., Inc., 454 U.S. 354, 360, 102 S. Ct. 695, 698, 70 L. Ed. 2d 542, 548 (1982) (per curiam) ("While the Court of Appeals may have reached a practical result, it was a result inconsistent with the unambiguous language used by Congress."); United States v. Bruguier, 735 F.3d 754, 774 (8th Cir. 2013) (citing Lamie, 540 U.S. at 538); Desha v. La. State Bd. of Nursing, No. 3:15-cv-00021-JWD-RLB, 2015 U.S. Dist. LEXIS 169861, at *15-16, 2015 WL 9307275, at *5 (M.D. La. Dec. 21, 2015) (same).

220 See, e.g., Hooker v. Constellation Homebuilder Sys., No. V-06-77, 2008 U.S. Dist. LEXIS 66008, at*21, 2008 WL 4057909, at *7 (S.D. Tex. Aug. 26, 2008) (observing that the Fifth Circuit appeared to interpret Rule 68 inconsistently with its "plain reading"); Connelly v. Hyundai Motor Co., 351 F.3d 535, 544 (1st Cir. 2003) ("Our interpretation of Rule 51 is quite strict."); Allred v. Kennerley (In re Kennerley), 995 F.2d 145, 147 (9th Cir. 1993) (strictly construing Federal Rule of Bankruptcy Procedure 4007). Due to the unquestionable differences between statutory and rule formation, a debate continues to rage over the suitability of the strict reading seemingly favored by the Court. See, e.g., Bernadette Bollas Genetin, The Powers that Be: A Reexamination of the Federal Courts' Rulemaking and Adjudicatory Powers in the Context of a Clash of a Congressional Statute and a Supreme Court Rule, 57 BAYLOR L. REV. 587, 596 \& n.26 (2005); Karen Nelson 
partly so as to increase judicial discretion and lawyers' latitude. ${ }^{221}$ Unlike statutes, moreover, rules implicate the so-called "trans-substantivity doctrine," 222 which dictates that each rule "should be viewed, not as [an] isolated fragment[], but as an integrated whole, and thus one rule cannot be read to circumvent another," 223 and the Rules Enabling Act. ${ }^{224}$ For this reason, the practical meaning of any discovery rule, including Rules 30 and 32, must not be deduced without consideration of the policies embodied in and strictures imposed by Rules 1 and 26,225 for this reason, the former must not be analyzed without cognizance of other provisions' text and structure; ${ }^{226}$ and for this reason, no rule's interpretation can upset

Moore, The Supreme Court's Role in Interpreting the Federal Rules of Civil Procedure, 44 HASTINGS L.J. 1039, 1091-96 (1993).

221 Subrin, Equity's Conquest, supra note 31, at 923-24. For instance, a recent dissent faults the majority for an interpretation "reminiscent of the writ-based common law pleading rules, which were so inflexible that a plaintiff that used the wrong writ was out of court," and which "had become [so] rigid and rarified" that "a party could easily lose on technical rules." Singer Mgmt. Consultants v. Milgram, 650 F.3d 223, 242 \& n.2 (3d Cir. 2011) (Roth, J., dissenting) (quoting Subrin, Equity's Conquest, supra note 31, at 917 (internal quotation marks omitted)); see also, e.g., Varhol v. Nat'l R.R. Passenger Corp., 909 F.2d 1557, 1570 (7th Cir. 1990) ("When enacting the Rules, "the rulemakers wanted to escape the rigidities and technicalities that had attended the development of procedural codes ...." (quoting Shapiro, supra note 31, at 1975)).

222 David Marcus, Past, Present, and Future of Trans-Substantivity in Federal Civil Procedure, 59 DePaUl L. REV. 371, 376-83 (2010); see also United States v. Hoffa, 497 F.2d 294, 296 (7th Cir. 1974) ("All of the Federal Rules of Civil Procedure . . must be interpreted in light of ... [Rule] 1.").

${ }_{223}$ Garza v. Webb Cnty., 296 F.R.D. 511, 512 (S.D. Tex. 2014); see also Cipollone v. Liggett Grp., Inc., 822 F.2d 335, 345 (3d Cir. 1987) (quoting with approval Cipollone v. Liggett Grp., Inc., 113 F.R.D. 86, 92-93 (D.N.J. 1986)); $c f$. Makaeff v. Trump Univ., LLC, 715 F.3d 254, 274 (9th Cir. 2009) (Kozinski, J., concurring) (“The Federal Rules aren't just a series of disconnected procedural devices. Rather, the Rules provide an integrated program of pre-trial, trial and post-trial procedures ...."); United States v. Aluminum Co. of Am., 1 F.R.D. 57, 58 (S.D.N.Y. 1939) (construing Rules 34 and 45, which "relate to the same subject [matter,]" in pari materia). For more on the relevant principle, see Marcus, supra note 222 , at $376-83$.

22428 U.S.C. $\$ 2072$ (2014) (establishing that rules of practice, procedure, and evidence "shall not abridge, enlarge or modify any substantive right"). For more on the Rules Enabling Act and its relationship to the trans-substantivity doctrine, see Shachmurove, supra note 23, at 531-33.

225 See, e.g., Marek v. Chesny, 473 U.S. 1, 21, 105 S. Ct. 3012, 3022-23, 87 L. Ed. 2d 1, 17 (1985); Herbert v. Lando, 441 U.S. 153, 177, 99 S. Ct. 1635, 1649, 60 L. Ed. 2d 115, 134 (1979); Marvin Lumber \& Cedar Co. v. PPG Indus., 177 F.R.D. 443, 444 (D. Minn. 1997) (relying in part on Hickman v. Taylor, 329 U.S. 495, 505, 67 S. Ct. 385, 391, 91 L. Ed. 451, 459 (1947))).

226 Shachmurove, supra note 23, at 528-34 (outlining the relevant principles of rule interpretation); see also, e.g., Lozano v. Bosdet, 693 F.3d 485, 489 (5th Cir. 2012) (engaging in an "holistic interpretation" of Rule 4); United States v. McCoy, 313 F.3d 561, 568 (D.C. Cir. 2002) (Henderson, J., dissenting) (faulting the majority for "tortur[ing]" the meaning of Federal Rule of Criminal Procedure 32(b)(6)(D) by "[r]ending a few phrases" from a statute's "broader context"); Allison v. Citgo Petroleum Corp., 151 F.3d 402, 412 
a party's statutorily gifted prerogatives. ${ }^{227}$ Lastly, despite the uniform disdain with which the judiciary has treated legislative history, rulemaking history, including the advisory committees' notes, have been consistently utilized by scholars and courts obliged to construe a federal rule. ${ }^{228}$ From language so contextually understood is any rule's operative meaning, its unambiguous and plain one, derived. ${ }^{229}$

B. Rules' Intimations

\section{Rule 30(c)(2)}

"[S]tated concisely," in "a manner" neither argumentative ("nonargumentative") nor suggestive ("nonsuggestive"), an objection must be under Rule 30(c)(2). ${ }^{230}$ Their purpose loudly proclaimed, ${ }^{231}$ this sentence's three short descriptors_-"concisely" modifies "stated," while "nonargumentative" and "nonsuggestive" modify "manner"-reappear without elaboration in the relevant advisory committee's note. Pursuant to "well established principles of interpretation," 232 these words" denotations and connotations must be pinpointed, each hinting at Rule 30(c)(2)'s core command, if an objection's befitting contours are to be correctly drawn.

As typically deployed in legal texts and common speech, "concisely" carries a specific and well-defined import, distinguishable from the

(5th Cir. 1998) (turning to "the principles and assumptions underlying the [Rule 23](b)(2) class and class actions in general to ascertain whether they add substance to the concept of predomination under Rule 23(b)(2)" when neither text nor precedent provided "clear guidance").

227 See, e.g., 28 U.S.C. § 2072; Semtek Int'l Inc. v. Lockheed Martin Corp., 531 U.S. 497, 503, 121 S. Ct. 1021, 1025-26, 149 L. Ed. 2d 32, 40 (2001) (construing 28 U.S.C. $\S 2072$ ); Ortiz v. Fibreboard Corp., 527 U.S. 815, 842, 119 S. Ct. 2295, 2313, 144 L. Ed. 2d 715, 738 (1999) (favoring a "limited construction" of Rule 23(b)(1)(B) that "minimize[d] potential conflict with the Rules Enabling Act, and avoid[ed] serious constitutional concerns").

228 E.g., Amchem Prods., Inc. v. Windsor, 521 U.S. 591, 614-17, 117 S. Ct. 2231. 2245-46, 138 L. Ed. 2d 689, 707-08 (1997) (interpreting FED. R. Civ. P. 23); Pioneer Invs. Servs. Co. v. Brunswick Assocs. Ltd. P'ship, 507 U.S. 380, 389, 113 S. Ct. 1489, 1495, 123 L. Ed. 2d 74, 85-86 (1993) (interpreting FED. R. BANKR. P. 9006(b)); BFP Invs., Inc. v. BFP Invs., Ltd., 150 F. App'x 978, 979 (11th Cir. 2005) (citing FED. R. BANKR. P. 9024 advisory committee's note (1983)). However, if Congress chooses to intervene and override a committee's particular proposal, its views should control. See Amir Shachmurove, Bankruptcy Rule 7004 after Espinosa: A Timely Distinction between Constitutional and Statutory Service, NORTON BANKR. L. ADVISER, June 2014 (examining one such example).

229 GARNER \& SCALIA, supra note 216, at 167-69.

230 FED. R. CIV. P. 30(c)(2).

231 FED. R. CiV. P. 30(d) advisory committee's note to 1993 amendment.

232 RadLAX Gateway Hotel, LLC v. Amalgamated Bank, 132 S. Ct. 2065, 2073, 182 L. Ed. 2d 967, 976 (2012); see also supra Part IV.A. 
meaning of the close and oft-conflated "succinct" and "brief." "Of speech or writing," "concise" means "expressed in few words," both "brief and comprehensive in statement" rather than "diffuse" or merely "brief.",233 "Comprehensive" connotes "large content or scope," a statement "inclusive" and "embracing"; 234 a "comprehensive" statement must therefore encompass all relevant detail, responsive in full, and not an iota more or less. ${ }^{235}$ Lexicographically, a "concisely stated" objection, the kind of objection required by Rule 30(c)(2), is "brief" but "comprehensive," 236 and cannot lack critically relevant information. ${ }^{237}$ To be concise is to be brief, yet to also include all relevant data; to be succinct is to be no more than brief. Such is the plainest gist of the word "concise."

This distinction finds support in other provisions, as "concisely" and such related yet dissimilar words as "clearly,"238 "simpl[y],"239 and "direct[ly]"240 litter the Rules. For example, a complaint that does not put a defendant on notice of all relevant claims and includes "a morass of irrelevancies" is not "concise," as Rule 8 demands. ${ }^{241}$ Instead, such a

233 Concise, OXFord English Dictionary (2d ed. 1989); accord Concise, OXFORD English Dictionary Online (3d ed. 2011); see also Metro. Milwaukee Ass'n of Commerce, Inc. v. City of Milwaukee, 798 N.W.2d 287, 297 (Wis. Ct. App. 2011) (accepting that "the common meaning of concise" is "marked by brevity in expression or by compact statement without elaboration or superfluous detail," a naturally disjunctive definition (citing WEBSTER's THIRD INTERNATIONAL DiCTIONARY 471 (1993))).

234 Comprehensive, OXFORD ENGLish Dictionary; accord Comprehensive, OXFORD ENGLish DiCTIONARY ONLINE; $c f$. Clear Creek Conservancy Dist. v. Kirkbride, 719 N.E.2d 852, 856 (Ind. Ct. App. 1999) (Friedlander, J., dissenting) (noting that, while the majority had not explained "the meaning of 'comprehensive' in this context," it could mean either "covers the matter completely, or nearly so, or . . is sizeable").

235 See Friends of Yosemite Valley v. Kempthorne, 520 F.3d 1024, 1037 (9th Cir. 2008) (noting that a river's "comprehensive management plan" must address all relevant, "inseparable" elements).

236 Concise, OXFord English Dictionary; accord Concise, OXFORD English DictionARY OnLine; see also Metro. Milwaukee Ass'n of Commerce, Inc. v. City of Milwaukee, 798 N.W.2d 287, 297 (Wis. Ct. App. 2011) ("The common meaning of 'concise' is 'marked by brevity in expression or by compact statement without elaboration or superfluous detail."” (quoting WEBSTER's THIRD NEW INTERNATIONAL DICTIONARY 471 (1993))).

${ }^{237}$ Cf. Hodgson v. Humphries, 454 F.2d 1279, 1282 (9th Cir. 1972) (commending a court's order for "succinctly, concisely and commendably" defining the relevant issues); FED. R. BANKR. P. 8014(a)(5), (7) (requiring "a concise statement of the applicable standard of appellate review" and "a succinct, clear, and accurate statement of the arguments made in the body of" an appellate brief).

238 FeD. R. CIV. P. 23(c)(2)(B) ("The notice must clearly and concisely state . . ."); Baumann v. Chase Inv. Servs. Corp., 747 F.3d 1117, 1122 n.2 (9th Cir. 2014).

239 FED. R. CIV. P. 8(d)(1) ("[E]ach allegation must be simple, concise, and direct."); Hickman v. Hickman, 563 F. App'x 742, 743 (11th Cir. 2014).

240 FED. R. CIV. P. 8(d)(1) ("[E] ach allegation must be simple, concise, and direct.").

241 United States ex rel. Garst v. Lockheed-Martin Corp., 328 F.3d 374, 378 (7th Cir. 2003). 
pleading's "lack of organization and basic coherence" renders it "too confusing to determine the facts that constitute the alleged wrongful conduct," the antithesis of comprehensive. ${ }^{242}$ In accordance with the presumption of consistent usage, ${ }^{243}$ one of the foremost principles of construction, ${ }^{244}$ a decision to inscribe one word-here, "concisely"-over "succinct," "direct," or "clear" in a specific rule's text within the same statutory $^{245}$ scheme merits deference. ${ }^{246}$ Indeed, this choice must be reckoned deliberate, any interpreter of Rule 30(c)(2) thereby bound to heed subtle distinctions in verifiable connotations.

242 Stanard v. Nygren, 658 F.3d 792, 797-98 (7th Cir. 2011) (quoting, among many, Garst, 328 F.3d at 378); see also Anderson v. Dist. Bd. of Trs. of Cent. Fla. Cmty. Coll., 77 F.3d 364, 366 (11th Cir. 1996) (noting that an improper complaint makes it "virtually impossible to know which allegations of fact are intended to support which claim(s) for relief").

243 United States v. Castleman, 134 S. Ct. 1405, 1417, 188 L. Ed. 2d 426, 440-41 (2014) (defining and applying the presumption).

244 Axiomatically, these principles are no more than rules of thumb. Griffith v. United States (In re Griffith), 206 F.3d 1389, 1393 (11th Cir. 2000) (quoting Conn. Nat'l Bank v. Germain, 503 U.S. 249, 253, 112 S. Ct. 1146, 1149, 117 L. Ed. 2d 391, 397 (1992)), cert. denied, 531 U.S. 826, 121 S. Ct. 73, 148 L. Ed. 2d 37 (2000); $f$. Richlin Sec. Serv. Co. v. Chertoff, 553 U.S. 571, 589, 128 S. Ct. 2007, 2019, 170 L. Ed. 2d 960, 974 (2008) (describing the sovereign immunity canon as "a tool for interpreting the law" that cannot "displace[] the other traditional tools of statutory construction").

245 See, e.g., Police \& Fire Ret. Sys. of City of Detroit v. IndyMac MBS, Inc., 721 F.3d 95, 107 n.14 (2d Cir. 2013) ("The Federal Rules of Civil Procedure ... have the force and effect of a federal statute." (internal quotation marks omitted)); Schneider v. Nat'l R.R. Passenger Corp., 72 F.3d 17, 19 (2d Cir. 1995) (same); Okla. Radio Assocs. v. FDIC, 969 F.2d 940, 942 (10th Cir. 1992) (same).

246 See, e.g., Sullivan v. Stroop, 496 U.S. 478, 484, 110 S. Ct. 2499, 2504, 110 L. Ed. $2 \mathrm{~d} 438,446$ (1990) (summarizing "the normal rule of statutory construction that identical words used in different parts of the same act are intended to have the same meaning" (internal quotation marks omitted)); United States v. Poff, 926 F.2d 588, 591 (7th Cir. 1991) ("Courts often say that the choice of different words reflects an intent to say something different." (citing Zabielski v. Montgomery Ward \& Co., 919 F.2d 1276, 1279 (7th Cir. 1990))); Energy Research Found. v. Def. Nuclear Facilities Safety Bd.,917 F.2d 581, 583 (D.C. Cir. 1990) ("[W]hen Congress employs the same word, it normally means the same thing, when it employs different words, it usually means different things." (quoting Henry J. Friendly, Mr. Justice Frankfurter and the Reading of Statutes, in BENCHMARKS 224 (1967))); cf. Samantar v. Yousuf, 560 U.S. 305, 317, 130 S. Ct. 2278, 2288, 176 L. Ed. 2d 1047, 1062 (2010) ("Drawing meaning from silence is particularly inappropriate ... [when] Congress has shown that it knows how to [address an issue] in express terms." (alteration in original) (quoting Kimbrough v. United States, 552 U.S. 85, 103, 128 S. Ct. 558, 571, 169 L. Ed. 2d 481, 485 (2007))). Of course, this presumption "readily yields to context." King v. Burwell, 135 S. Ct. 2480, 2493 n.3, 192 L. Ed. 2d 483, 498 n.3 (2015). Yet, especially when definitional distinctions exist and differently understood words have been inputted within the same compendium, i.e. the Rules, by seemingly careful drafters, this presumption is not easily overturned. At the very least, a substantive answer must be made, not silence chosen. In this particular case, moreover, context actually favors the presumption's application. See infra Part IV.B.2-C. 
In the maelstrom surrounding form objections, the plain import of Rule 30(c)(2)'s "concisely" is dispositive. Linguistically, if the exact basis for an objection cannot be fully conveyed by "form" alone, no objection can be deemed comprehensive, and it therefore cannot be branded "concise," Rule 30's sole explicit constraint. It thus greatly matters that, due to the inherent indeterminacy in the meaning of "form," 247 a simple form objection can never convey the sole salient grounds of another's opposition. Such an objection may be deemed brief, but "form" is so diffuse in connotation that any number of inapposite bases, from "ambiguous" to "speculative" to even "foundation," 248 can be implied by its exclamation. By any real measure, the number of objections conceivably encompassed by the term "form" is too difficult to demarcate precisely and authoritatively, and "form" is too vague to incorporate each and every proper basis - and nothing more-when first stated. ${ }^{249}$ With "form" so devoid of patently ascertainable content, a simple form objection cannot be described as "comprehensive" and as "concisely stated"; only a precise form objection can be so characterized. ${ }^{250}$ Accordingly, if Rule 30(c)(2)'s gravid language is plainly read, an inference follows: the exact nature of the objection to form, whether "leading" or "ambiguous," must be adduced for the objection to be "concise," as Rule 30's "comprehensive" requirement impliedly demands. While, short of unprovable telepathy between lawyers (and amateur grammarians), no simple form objection can guarantee this outcome, a precise form objection always can, its usage therefore consistent with Rule $30(c)(2)$ 's written text and certain purpose. ${ }^{251}$

247 See supra Part III.A.

248 Id.

249 Sec. Nat'l Bank of Sioux City v. Abbott Labs., 299 F.R.D. 595, 601 (N.D. Iowa 2014), rev'd, 800 F.3d 936 (8th Cir. 2015); cf. Osborne v. Mt. Empire Operations, LLC, No. 1:14CV00042, 2015 U.S. Dist. LEXIS 76732, at*4, 2015 WL 3745136, at *2 (W.D. Va. June 15, 2015).

250 Abbott Labs., 299 F.R.D. at 602-03.

251 See MD. R. CIV. P. CIR. CT. 2-415(g) committee's note ("Objections should be stated as simply, concisely, and non-argumentatively as possible to avoid coaching or making suggestions to the deponent and to minimize interruptions in the questioning of the deponent. Examples include 'objection, leading;' 'objection, asked and answered;' and "objection, compound question."”). The Texas' Rules of Civil Procedure incorporate the same "clear and concise," "nonargumentative," and "nonsuggestive" standard. TEX. R. CIV. P. 199.5(e). Interestingly, rule 199.5(e) appears to identify simple and precise form objections as equally acceptable. Id. Nonetheless, paragraph (f), applicable when instructions not to answer are given, states: "The attorney instructing the witness not to answer must give a concise, nonargumentative, nonsuggestive explanation of the grounds for the instruction if requested by the party who asked the question." Id. 199.5(f). Many have construed this paragraph to permit only simple form objections in general. See, e.g., Alyson Nelson, Comment, Deposition Conduct: Texas's New Discovery Rules End UP Taking Another Jab at the Rambos of Litigation, 30 TEX. TECH. L. REV. 1471, 1492 (1999); 
Focused on an objection's disparate effects on different entities, Rule 30(c)(2)'s "non-argumentative" and "non-suggestive" requirements lend further support to this deduction. A "suggestive" assertion is "[c]alculated or fitted to suggest thoughts, ideas, [or] a course of action"; it decidedly "convey[s] a suggestion or hint" and "impl[ies] something that is not directly expressed." 252 Unsurprisingly, Black's Law Dictionary defines a "suggestive question" as a "leading" one, and a "leading question" as "[a] question that suggests the answer to the person being interrogated." ${ }^{253}$ An "argumentative" statement has a recognizable purpose_-"influencing the mind" - and urges "a reason . . . in support of a proposition." 254 Under Rule 30(c)(2), an objection's "manner," i.e. its mode of presentation, must be non-suggestive and non-argumentative. Thus, even if a precise form objection seems to suggest an answer or evince hostility to the questioner's line of inquiry, it does not run afoul of Rule 30(c)(2). Conversely, if that objection is stated in such a way as to affect the substantive content of a deponent's answer by attempting to substitute the deponent's natural and reflexive answer with his or her lawyer's version, Rule 30(c)(2) will have been violated. Rule 30(c)(2)'s "non-suggestive" and "non-argumentative" prongs together predicate an objection's propriety on the extent to which it can be said to reasonably affect the substantive tenor of a deponent's testimony.

Crucially, as long as it is "verbally economical, stating the basis of the objection and nothing more" (e.g., "leading," or "nonresponsive"), ${ }^{255}$ a precise form objection has no such certain effect. Having exposed no more than the pertinent question's structural weakness, such an objection does not supplant the deponent's natural and substantive response with the lawyer's own. No deponent could reasonably glean from a precise form objection how the issue probed must be substantively answered, for the fact that a question is attacked as "ambiguous" or "asked and answered"

Nathan L. Hecht \& Robert H. Pemberton, A Guide to the 1999 Texas Discovery RULES REVISIONS 11 (1998). Logically, however, if an explanation can be "concise," "nonargumentative," and "nonsuggestive," so could have been the original objection, as Rule 30(c)(2) alone requires.

252 Suggestive, OXford English Dictionary; accord Suggestive, OXford English DICTIONARY ONLINE.

253 Suggestive Question, Leading Question, BLACK's LAW Dictionary (10th ed. 2014).

254 Argumentative, OXFORD ENGLISH DictionARY; accord Argumentative, OXFORD ENGLish Dictionary OnLine; see Dresser Indus. v. Smith-Blair, Inc., 322 F.2d 878, 886 n.1 (9th Cir. 1963) (commentating that " $[\mathrm{t}]$ he meaning of argumentative that appellant apparently had in mind is that the statement of fact is based on an inference").

255 Damaj v. Farmers Ins. Co., 164 F.R.D. 559, 561 (N.D. Okla. 1995); accord, e.g., Breaux v. Haliburton Energy Servs., Civ. Act. Nos. 04-1636 c/w 05-0896, 05-0897 Section "S" (4), 2006 U.S. Dist. LEXIS 59526, at*13, 2006 WL 2460748, at *3 (E.D. La. Aug. $22,2006)$. 
does not concurrently supply a deponent with his or her lawyer's favored reply. In fact, regardless of the objection's propriety and its making, the deponent must still answer the original demand if the questioner chooses not to remodel his or her defective question, and merely restating the question without any adjustment would leave the deponent with no other option. Realistically, therefore, a precise form objection is neither "suggestive" nor "argumentative" if it concerns, as it must, only a defect in form. ${ }^{256}$

Aside from this slight difference, precise and simple form objections are likely to have similar repercussions. Necessarily, a precise form objection triggers a dispute over the question advanced, and it does provide a deponent with a few more minutes to ruminate. Yet, a simple form objection does no less, for it too leads to a momentary pause and may prompt an argument between the antagonistically inclined. Moreover, as any resulting dispute centers on a question's form, a precise form objection does not effectively swap the content of a witness' answer with a lawyer's preferred legal retort; only further commentary beyond "leading" or "compound" will lead to such a substitution by astute witnesses. In short, prone to the same abuse as its simpler analogue, a precise form objection is no more argumentative and suggestive than a simple form one, its use no more encumbered by Rule 30(c)(2)'s manner restrictions.

\section{Rule $30(d)$}

Although not one directly concerns an objection's style and form, three other paragraphs in Rule 30(d) bear on the debate over form objections.

Rule 30(d)(1) creates a "presumptive durational limitation" 257 for every deposition of " 1 day of 7 hours" in the absence of a stipulation or judicial order, ${ }^{258}$ though "[p]reoccupation with timing is [nonetheless] to be avoided." ${ }^{259}$ The standard to be applied in adjudicating such extensions appears in the next sentence: if either the questioner needs "additional time" so as "to fairly examine the deponent" or "the deponent, another person, or any other circumstance impedes or delays the examination," "additional time," a request itself subject to Rule 26(b)(2)(C), may be

256 See Md. R. Civ. P. CiR. CT. 2-415(g) committee's note; $c f$. People v. Williams, 294 P.3d 1005, 1024 (Cal. 2013) (so defining "argumentative").

257 FED. R. CIV. P. 30(d) advisory committee's note to 2000 amendment.

258 FeD. R. Civ. P. 30(d)(1); Thompson v. Panos X Foods, Inc., No. 2:14-CV-10620, 2014 U.S. Dist. LEXIS 166785, at*6, 2014 WL 6632202, at*2 (E.D. Mich. Nov. 21, 2014).

259 FED. R. CIV. P. 30 advisory committee's note to 2000 amendment; Chawla v. Metro. Oral Surgery Assocs., P.C., No. 11-CV-6248 (RRM) (VMS), 2014 U.S. Dist. LEXIS 132541, at*15, 2014 WL 4678023, at*6 (E.D.N.Y. Sept. 19, 2014). 
allowed. ${ }^{260}$ Rule 30(d)(2) empowers a court to "impose an appropriate sanction" on any person "who impedes, delays, or frustrates the fair examination of the deponent."261 Mirroring Rule 30(d)(1), it bases sanctions on the extent to which "the fair examination of the deponent" has been impeded. ${ }^{262}$ Finally, Rule 30(d)(3)(A) permits "the deponent or a party" to terminate a deposition "on the ground that it is being conducted in bad faith or in a manner that unreasonably annoys, embarrasses, or oppresses the deponent or party."263 Although Rule 30(d)(3)(A) does not explicitly codify a fairness standard, the advisory committee insisted that it did, explaining that a deposition's termination is justified only if a "fair examination" is "unreasonably prolonged" or "improperly frustrated" by the making of "improper objections" or "an excessive number of unnecessary objections" or the "giving direction not to answer prohibited by paragraph (1)." 264 In these three paragraphs, two words loom large: "fair" and "unreasonable." Sprinkled with such inherently discretionary terms, ${ }^{265}$ Rule 30(d)(3) targets specific ills, its dominant message - that a deposition must be fair - relevant to the choice between simple and precise form objections in at least two ways.

First, in its modern iteration, Rule 30(d)(1) represents a deliberate and revealing truncation. ${ }^{266}$ Previously, Rule 30(d)(1) did not designate a witness' fair examination as the measure for modifying the Rule's time limitations; instead, it referenced "objections 'to evidence' and limitations on 'evidence." 267 "[T] $]$ avoid disputes about what is 'evidence' and whether an objection is to, or a limitation is on, discovery instead," however, these allusions were subsequently removed. ${ }^{268}$ In other words,

260 FeD. R. CIV. P. 30(d)(1), 26(b)(2); Perkins v. Nat'l Express, No. 14-cv-02347-NC, 2015 U.S. Dist. LEXIS 11330, at *6-7, 2015 WL 428395, at *2-3 (N.D. Cal. Jan. 30, 2015) (granting an additional two hours).

261 Fed. R. Civ. P. 30(d)(2); Ryan v. Astra Tech, Inc., 772 F.3d 50, 56 (1st Cir. 2014).

262 Fed. R. Civ. P. 30(d); FED. R. Civ. P. 30(d) advisory committee's note to 2000 amendment.

263 Fed. R. Civ. P. 30(d)(3)(A); Jenkins v. Miles, 553 F. App'x 638, 640 (7th Cir. 2014).

264 FED. R. CIV. P. 30(d) advisory committee's note to 1993 amendment.

265 See Rhodes, supra note 208, at 294-95 (identifying a number of words that, when used in the Bankruptcy Code, imply grant of judicial discretion, including "fair" and "reasonable").

266 See, e.g., FAA v. Cooper, 132 S. Ct. 1441, 1460-61, 182 L. Ed. 2d 497, 522-23 (2012) (Sotomayor, J., dissenting) (criticizing the majority for its view of a certain deletion's significance); United States v. Ressam, 553 U.S. 272, 275-77, 128 S. Ct. 1858, 1861-62, 170 L. Ed. 2d 640, 644-45 (2008) (finding a substitution and a deletion to be convincing evidence of congressional intent); Carter v. United States, 530 U.S. 255, 270 71, 120 S. Ct. 2159, 2169-70, 147 L. Ed. 2d 203, 217-18 (2000) (rejecting appellant's argument that a 1948 deletion was stylistic and indicated no intent).

267 FED. R. CIV. P. 30(d) advisory committee's note to 2000 amendment.

268 Id. 
Rule 30(d)(1) was modified so as to minimize inherently vague objections that cannot but prolong a deposition by either inducing technical debates on the applicability of a particular objection or leaving the questioner uncertain about the specific defect in his or her question to which his opponent has objected. As the exactly germane meaning of "form" is rarely clear, ${ }^{269}$ the use of simple form objections stymies this aspiration's realization. Because, by definition, such an objection fails to disclose its precise and exclusive root, a simple form objection encourages the kind of debate-inducing ambiguity and uncertainty that the advisory committee's removal of any references to "evidence" in Rule 30(d)(1) was designed to inhibit. Unquestionably, the advisory committee wanted to avoid disputes over technicalities when a legitimate objection, necessitated by Rule $30(\mathrm{~d})(3)$, is made; logically, any interpretation that interjects more uncertainty into Rule 30's application cannot but interfere with this particular mission. Based on one deletion's implication, then, precise form objections appear preferable to simple form ones, as they offer up detail and may consequently check needless obfuscation and, with it, controversy.

Second, Rule 30(d)'s standard appears either to favor precise form objections or, at the very least, not ban them outright. Rule 30(d)(1) and (2) predicate the granting of additional time or the imposition of sanctions on the extent to which a deponent's "fair examination" has been arrested, ${ }^{270}$ and even a non-suggestive and non-argumentative objection permissible under Rule 30(c)(2) may be deemed "unnecessary," punishable by these two paragraphs. ${ }^{271}$ According to the advisory committee, these provisions were inserted so as to "authorize[] the court to impose the cost resulting from obstructive tactics that unreasonably prolong a deposition on the person engaged in such obstruction." 772 "[O]verlong depositions," resulting in "undue costs and delays in some circumstances," spurred this requirement's engraftment and the creation of Rule 30(d)(2)'s "good cause" standard. ${ }^{273}$ Ever variable, such an analysis incorporates "a variety of factors," 274 "includ[ing] events

\footnotetext{
269 Interestingly, per its comment, this decision seemingly reflected the advisory committee's recognition of the problem posed by certain legal classifications' amorphous character. "Form," of course, is one such problematic label. See supra Part III.A.

270 FED. R. CIV. P. 30(d) advisory committee's note to 2000 amendment.

271 Fed. R. Civ. P. 30(d)(1)-(2); Craig v. St. Anthony’s Med. Ctr., 384 F. App'x 531, 533 (8th Cir. 2010).

272 FED. R. CIV. P. 30(d) advisory committee's note to 1993 amendment.

273 FED. R. CIV. P. 30 advisory committee's note to 2000 amendment; Martensen v. Koch, 301 F.R.D. 562, 585 (D. Colo.2014); Withers v. eHarmony, Inc., 267 F.R.D. 316, 321 (C.D. Cal. 2010).

274 FeD. R. CIV. P. 30(d) advisory committee's note to 2000 amendment.
} 
occurring over a long period of time, the need fully to explore the theories upon which the witness relies, or, in multi-party cases, the need for each party to examine the witness with the understanding that duplicative questioning is to be avoided." 275 Often, justification will be found "where new information comes to light triggering questions that the discovering party would not have thought to ask at the first deposition," 276 or "if the examining party was inhibited from conducting a full examination as a result of obstructive conduct at the first deposition."277 Commentary defines a "fair" and "full" examination in the negative: "In general, counsel should not engage in any conduct during a deposition that would not be allowed in the presence of a judicial officer." ${ }^{278}$

If one honors this theme, any familiar type of form objection, whether precise or simple, cannot be deplored. As both forms reappear with regularity in American courtrooms, precise form objections cannot be derided as the "unreasonable" tocsins of an "unfair" trial. And, even if simple ones do meet the minimum of necessity, a judicious use of precise form objections that is targeted at patent defects does not amount to the "excessive number of unnecessary objections" sanctionable under Rule 30(d). ${ }^{279}$ Such circumspect interruptions address specific flaws with more precision than a simple form objection can ever accomplish, and they are not "unnecessary" so long as the defect professed actually plagues the question posed. A precise form objection may lengthen a deposition, ${ }^{280}$ but it does not provide the witness with an excuse not to respond in full to the question posed. In this context, a precise form objection does not manufacture an unjust impediment to the examiner's line of inquiry, as the

275 Pratt v. Archstone Willow Glen Apartments, No. C08-3588 JF (RS), 2009 U.S. Dist. LEXIS 63550, at*3, 2009 WL 2032469, at*1 (N.D. Cal. July 10, 2009).

276 Boston Sci. Corp. v. Cordis Corp., Nos. 5:02-cv-1474 JW (RS), 03-cv-5669 JW (RS), 2004 U.S. Dist. LEXIS 18098, at*9, 2004 WL 1945643, at *2 (N.D. Cal. Sept. 1, 2004).

277 Morrison v. Stephenson, No. 2:06-cv-0283, 2008 U.S. Dist. LEXIS 6512, at *5, 2008 WL 145017, at*1 (S.D. Ohio Jan. 10, 2008).

278 FED. R. CIV. P. 30(d) advisory committee's note to 1993 amendment; see also Sec. Nat'l Bank v. Jones Day, 800 F.3d 936, 942 (8th Cir. 2015) (contending, based on this comment, that Rule 30(d) was intended to "deter" such conduct); Hunt v. DaVita, Inc., 680 F.3d 775, 780 (7th Cir. 2012) ("Coaching and private conferences (on issues other than privilege) that would be inappropriate during trial testimony are not excused during a deposition merely because the judge is not in the room.").

279 FED. R. CIV. P. 30(d) advisory committee's note to 1993 amendment; see also Craig v. St. Anthony's Med. Ctr., 384 F. App'x 531, 533 (8th Cir. 2010) (observing that a record revealing "a substantial number of argumentative objections together with suggestive objections and directions to the deponent to refrain from answering questions without asserting a valid justification under Rule 30(c)(2)" provided "ample support" for the district court's finding that opposing counsel had "impeded, delayed, or frustrated the deposition").

280 This proposition is debatable. For example, "Objection, ambiguous," or, "Objection, compound," consists of no more words than "Objection, form." 
objection must be made to be preserved, the question must still be answered, and no civil trial has been made unfair by its muttering. In light of these reasons, precise form objections do not appear to be inherently "improper" or "unnecessary," none normally verboten during a "fair examination."

\section{Rule 32(d)(3)}

Leaving the phrase "objection to the form of a question" undefined, Rule 32(d)(3)(B) mostly treats such objections no differently than those to "the manner of taking the deposition" or a "party's conduct." 281 Admittedly, it does require that such objections be "timely made during the deposition," 282 but it does not otherwise distinguish between "[a]n objection to an error or irregularity at an oral deposition" and one to "a deponent's competence ... or the competence, relevance, or materiality of testimony."283 All objections to "form" and to "materiality," it pronounces, will be deemed waived if the specific defect charged "might have been corrected" at the time of examination itself and if they were not then voiced. ${ }^{284}$ As written and conceived, the test for waiver in Rule 30(d)(3)(B) is intended to be congruent with Rule 30(c)(2)'s "concisely stated" criterion ${ }^{285}$ and differentiates amongst the law's manifold objections on the basis of "whether the problem could have been cured at the deposition," ${ }^{286}$ utility its lodestar. It hence stresses "the necessity of making the objection at a point in the proceedings where it will be of some

281 Fed. R. Civ. P. 32(d)(3)(B)(i); NGM Ins. Co. v. Walker Constr. \& Dev. LLC, No. 1:11-CV-146, 2012 U.S. Dist. LEXIS 177161, at*4, 2012 WL 6553272, at*1 (E.D. Tenn. Dec. 13, 2012).

282 FeD. R. Civ. P. 32(d)(3)(B)(ii); Berlinger v. Wells Fargo, N.A., No. 2:11-cv-459FtM-29CM, 2014 U.S. Dist. LEXIS 134643, at*14-15, 2014 WL 4783156, at *5 (M.D. Fla. Sept. 24, 2014).

283 Compare FeD. R. Civ. P. 32(d)(3)(B), with FeD. R. CIV. P. 32(d)(3)(A); Kirschner v. Broadhead, 671 F.2d 1034, 1037-38 (7th Cir. 1982) (concluding that objections to form, now encompassed by Rule 32(d)(3)(B), and to relevancy, presently covered by Rule 32(d)(3)(A), are waived if the relevant error could have been obviated during the actual deposition).

284 FeD. R. Civ. P. 32(d)(3)(A), (B)(i); see also, e.g., Darwin v. Nicholson, 221 F. App'x 918, 920 (11th Cir. 2007) (interpreting Rule 32(d)(3)(B)); Wensley v. Scott, 459 F. Supp. 2d 388, 391 (W.D. Pa. 2006) (construing Rule 32(d)(3)(A)).

285 FED. R. CIV. P. 30(d) advisory committee's note to 1993 amendment ("While objections may, under the revised rule, be made during a deposition, they ordinarily should be limited to those that under Rule 32(d)(3) might be waived if not made at that time, i.e., objections on grounds that might be immediately obviated, removed, or cured, such as to the form of a question or the responsiveness of an answer."); Southgate v. Vermont Mut. Ins. Co., No. CA 06-500 ML, 2007 U.S. Dist. LEXIS 45291, at*12, 2007 WL 1813547, at $* 4$ (D. Vt. June 21,2007$)$.

286 James W. McElhaney, Objecting at Depositions, LiTIG., Summer 1988, at 52. 
value in curing the alleged error in the deposition" 287 and strives to "render technical objections based on errors and irregularities in depositions unavailable at trial." 288 Any other formulation will likely embolden counsel "to wait until trial before making any objections, with the hope that the testimony, although relevant, would be excluded altogether because of the manner in which it was elicited."289 Though the objection may have once been curable, it has since lost its efficacy, and this silence will lead to the exclusion of evidence on the basis of a formality whose trespass could have been corrected without handicapping the search for truth, Title V's famed ambition. It is such an unproductive outcome that is anathema to Rule 32(d)(3) and, by implication, the roughly coterminous Rule 30(c)(2), the maximization of an objection's utility and the minimization of nonfunctional objections its chief interests.

Quite simply, a precise form objection can satisfy this focus in a way no simple form objection ever could. As a matter of pure denotation, the amorphous "form" can rarely aid the questioner, as Rule 32(d)(3) requires for waiver to be possible and as Rule 30(c)(2) implicitly requires for an objection to be properly formed. Too thalassic, in and of itself, a simple form objection does not divulge its specific ground short of improbable congruencies: a perfectly identical perception regarding every possible irregularity's singular denotation and its natural application between contending lawyers and their shared and equal willingness not to exploit a technical defect for a later tactical advantage. Naturally, these two occurrences' simultaneous probability is belied not only by the questioner's willful decision to pose an enquiry despite what another lawyer finds to be an obvious defect in form but also by longstanding disagreements amongst scholars and courts about both the kind of objections subsumed within "form" 290 and the particular relevance of any

287 Bahamas Agric. Indus., Ltd. v. Riley Stoker Corp., 526 F.2d 1174, 1181 (6th Cir. 1975); see also, e.g., Webb v. Hiben, No. 12-12370, 2015 U.S. Dist. LEXIS 125998, at *6, 2015 WL 5439216, at *2 (E.D. Mich. Sept. 15, 2015); Kirschner, 671 F.2d at 1037-38; cf. Osborne v. Wenger, 572 N.E.2d 1343, 1348 (Ind. Ct. App. 1991).

288 Wilmington v. J.I. Case Co., 793 F.2d 909, 921 (8th Cir. 1986) (internal quotation marks omitted).

289 Bahamas Agric. Indus., Ltd., 526 F.2d at 1181; cf. Cabello v. Fernandez-Larios, 402 F.3d 1148, 1160 (11th Cir. 2005) ("The rules distinguish objections to the manner of taking the deposition from objections as to the substance of the testimony (such as relevancy or competency) because allowing counsel to wait until trial to object might encourage sandbagging.").

290 See, e.g., Perez v. Bruister, Nos. 3:13cv1001-DPJ-FKB, 3:13cv1081-DPJ-FKB, 2014 U.S. Dist. LEXIS 104838, at *6, 2014 WL 3779640, at*1 (S.D. Miss. July 31, 2014) (observing that "[t]he parties frequently object based on 'lack of foundation' or "speculation"" and adding that "it is difficult to tell whether the objections are substantive or based on the form of the question"). 
one objection, such as "leading" 291 or "ambiguous," 292 to numberless questions. As such, a precise form objection aligns with a utility-minded Rule 32(d)(3) for a single and simple reason. It affords the examiner the chance to promptly correct a mistake that may otherwise produce unclear answers in defiance of discovery's venerable purposes, its utterance likelier to yield more unveiled facts and winnowed issues than the farraginous simple form objection.

By compelling a party to state its form objection's basis, such an approach has an added practical benefit. It allows an outside observer, most especially a court asked to review a record of objections under Rule 30 (d), to discern the extent to which the objection has been interposed for an improper motive. ${ }^{293}$ Forced to be specific about the alleged irregularity, an objector can no longer try to justify an interruption by ex post facto reasoning. During the deposition itself, the purported defect must be "timely" identified, making that interruption's reasonableness and objector's good faith easier to gauge ever afterward. In this way, precise form objections will make it much simpler for a court to punish the "abusive" exploitation of objections, no lawyer able to rely on the ambiguity inherent to "form" to explain away unmerited interruptions. If the question was not "asked and answered," but he or she protested on that basis, that disturbance's unnecessity is more evident. And if the question was not "compound," but he or she objected for that reason, that interruption's impropriety is more obvious. By itself, "form," in contrast, offers the prized refuge of ambiguity, an objector's bad faith harder to establish when "form" can imply so much. So understood, a precise form objection is rather useful, as will be shown more fully below. ${ }^{294}$

\section{Broader Context}

The foregoing reading is bolstered by the Rules' broader context, the verifiable vision which lies at their very center. ${ }^{295}$ In the words of one

291 Cf. 1 Charles T. MCCORMiCK ET AL., MCCORMiCK ON EvidenCe $§ 6$ (4th ed. 1992) ("It is a common misconception that all questions asking for a 'yes' or 'no' answer are leading.").

292 See Peter M. Tiersma, The Language of Perjury: "Literal Truth," Ambiguity, and the False Statement Requirement, 63 S. CAL. L. REV. 373, 421 (1989) (defining "an ambiguous question" as "one that has a number of fairly specific possible interpretations," but noting that "[a] further possible classification, not usually made explicit by the courts, if the vague question," within the law of perjury (emphasis in original)).

293 Sec. Nat'l Bank of Sioux City v. Abbott Labs., 299 F.R.D. 595, 602-03 (N.D. Iowa 2014), rev'd, 800 F.3d 936 (8th Cir. 2015); Mayor \& City Council of Baltimore v. Theiss, 729 A.2d 965, 976 (Md. 1999).

294 For more on this point, see infra Part IV.C.

295 Hunt v. DaVita, Inc., 680 F.3d 775, 780 (7th Cir. 2012) (highlighting the "factfinding purpose of a deposition"); accord, e.g., Pain Ctr. of SE Ind., LLC v. Origin 
court, "the purpose of a deposition is to memorialize testimony or to obtain information that can be used at trial or that eliminates the pursuit of issues or that inform decisions as to the future course of the litigation ... before the recollection of events fade or 'it has been altered by . . . helpful suggestions of lawyers.",296 Faced with counsel's incessant pressure, examination and cross-examination afford a live witness "no opportunity to reflect and carefully shape the information given," 297 as the examiner can delve into another's case ${ }^{298}$ and nitpick "the veracity and contours of" any statements made by means of "probative follow-up questions."299 "The fact that the interrogation is conducted orally" maximizes the probability of extracting admissions and information that a witness may naturally "be reluctant to make or . . . hesitate to reveal." ${ }^{300}$ Interrogatories may often be devastating, ${ }^{301}$ and a mental examination may occasionally reveal pivotal data. ${ }^{302}$ Nonetheless, in the judicial and scholarly

Healthcare Solutions, LLC, No. 1:13-cv-00133-RLY-DKL, 2015 U.S. Dist. LEXIS 98071, at *14, 2015 WL 4548528, at *5 (S.D. Ind. July 28, 2015); see also Blair v. CBE Grp., Inc., No. 13-CV-00134-MMA (WVG), 2015 U.S. Dist. LEXIS 67920, at *26, 2015 WL 3397629, at *10 (S.D. Cal. May 26, 2015).

296 E.I. du Pont de Nemours \& Co. v. Kolon Indus., 277 F.R.D. 286, 297 (E.D. Va. 2011) (internal quotation marks omitted) (citing Hall v. Clifton Precision, 150 F.R.D. 525, 528 (E.D. Pa. 1993)).

297 Alexander v. FBI, 186 F.R.D. 113, 121 (D.D.C. 1998) (internal quotation marks omitted).

298 This belief may explain why oral depositions under Rule 30 are favored over written depositions pursuant to Rule 31. The latter questioning does not "permit the probing follow-up questions necessary in all but the simplest litigation" or allow counsel "to observe the demeanor of the witness and evaluate his credibility in anticipation of trial" and actually "provide[s] an opportunity for counsel to assist the witness in providing answers so carefully tailored that they are likely to generate additional discovery disputes." Mill-Run Tours, Inc. v. Khashoggi, 124 F.R.D. 547, 549 (S.D.N.Y. 1989) (citing for support Nat'l Life Ins. Co. v. Hartford Accident \& Indem. Co., 615 F.2d 595, 599-600 n.5 (3d Cir. 1980), and Alliance to End Repression v. Rochford, 75 F.R.D. 428, 429 (N.D. Ill. 1976)); see also, e.g., United States v. \$160,066.98 from Bank of Am., 202 F.R.D. 624, 630-31 (S.D. Cal. 2001) (discussing the disadvantages of written questions).

299 Cavanaugh v. Wainstein, No. 05-123 (GK), 2007 U.S. Dist. LEXIS 40242, at*33, 2007 WL 1601723, at *10 (D.D.C. June 4, 2007) (internal quotation marks omitted) (citing, among others, Alexander, 186 F.R.D. at 121).

300 Holtzoff, supra note 93, at 209-10; see also Societe Nationale Industrielle Aerospatiale v. U.S. Dist. Ct. for S. Dist. of Iowa, 482 U.S. 522, 540 n.25, 107 S. Ct. 2542, 2553 n.25, 96 L. Ed. 2d 461, 481 n.25 (1987) (emphasizing discovery's "fundamental maxim that mutual knowledge of all relevant facts gathered by both parties is essential to proper litigation" (internal quotation marks omitted)). This author made a point of emphasizing the non-deponent's ability to circumvent Rule 34 by employing a subpoena duces tecum. Holtzoff, supra note 93, at 220-221.

301 See Sonnino v. Univ. of Kan. Hosp. Auth., 220 F.R.D. 633 (D. Kan. 2004).

302 See Kermit S. King, A Study of Rule 35 of the Federal Rules of Civil Procedure, 11 S.C. L. Q. 183, 194 (1959). 
imagination, their importance pales before that of an oral deposition's, its "rank high in the hierarchy of pre-trial, truth-finding mechanisms."

Driven by this belief, "objections and colloqu[ies]" have been denounced for "unduly prolong[ing], if not unfairly frustrat[ing], [depositions]." 304 They daily threaten another's "ability to obtain meaningful testimony and unnecessarily add[ing] to the expense of litigation." ${ }^{305}$ In the opinions of many, their ubiquity has rendered the attainment of Rule 30's "underlying" purpose-"to find out what a witness saw, heard, or did - what the witness thinks - [through] a question-andanswer conversation between the deposing lawyer and the witness"nearly impossible. ${ }^{306}$ When the Rules were re-hauled with the addition of Rule 30(c), the drafters hoped to minimize these dangers. That is to say, they remade discovery procedure so as to assure solely "testimony from the witness, not from counsel, and without suggestions from counsel"307 would be elicited and no "legally convenient record" could be molded by another's disturbances. ${ }^{308}$

A precise form objection, not a simple form one, effectively ensures these objectives' fulfillment. By identifying a specific fault that may produce an answer unintentionally ambiguous, a precise form objection informs the questioner of an apparent defect's nature. Now cognizant of the existence of one or more specific flaws, he or she can intelligently attempt to modify a question's structure and pose another more likely to elicit meaningful testimony. Upon this correction, more easily and promptly completed once a particular question's deficiency has been exactly identified, the utility of the answer given less likely to be hampered by an unknown structural imperfection which, if left uncorrected, can

303 Founding Church of Scientology v. Webster, 802 F.2d 1448, 1451 (D.C. Cir. 1986); accord U.S. Dep't of Treasury v. Pension Benefit Guar. Corp., 301 F.R.D. 20, 30 (D.D.C. 2014).

304 FED. R. CIV. P. 30(d) advisory committee's note to 1993 amendment; Luangisa v. Interface Operations, No. 2:11-cv-00951-RCJ-CWH, 2011 U.S. Dist. LEXIS 139700, at *21, 2011 WL 6029880, at*7 (D. Nev. Dec. 5, 2011); McDonough v. Keniston, 188 F.R.D. 22, 24 (D.N.H. 1998).

305 Thon v. Transp. TFI 11, S.E.C., No. 13-13365, 2014 U.S. Dist. LEXIS 117696, at *5, 2014 WL 4206888, at *2 (E.D. Pa. Aug. 22, 2014) ; see also, e.g., United States v. Kattar, 191 F.R.D. 33, 38 (D.N.H. 1999); Am. Directory Serv. Agency v. Beam, 131 F.R.D. 15, 18 (D.D.C. 1990).

306 Hall v. Clifton Precision, 150 F.R.D. 525, 528 (E.D. Pa. 1993); accord, e.g., Lund v. Matthews, No. 8:13CV144, 2014 U.S. Dist. LEXIS 15863, at*9-10, 2014 WL 517569, at *4 (D. Nev. Feb. 7, 2014) (citations omitted); State Farm. Mut. Auto. Ins. Co. v. Dowdy, 445 F. Supp. 2d 1289, 1292 (N.D. Okla. 2006); Johnson v. Wayne Manor Apartments, 152 F.R.D. 56, 59 (E.D. Pa. 1993).

307 Hunt v. DaVita, Inc., 680 F.3d 775, 780 (7th Cir. 2012).

308 Caso v. Luzerne Cnty., No. 3:13-CV-02253, 2015 U.S. Dist. LEXIS 55543, at*48, 2015 WL 1951610, at*17 (M.D. Pa. Apr. 28, 2015) (citing Hall, 150 F.R.D. at 528). 
provoke a response open to several contrasting substantive interpretations and not one reasonable exposition. In short, a precise form objection can lead to a better deposition, one which hones more issues and brings to the forefront more facts than an interrogation punctured by less targeted protestations.

In certain cases, precise form objection can do something more. Compelled to utter only such objections, the lawyer determined to interrupt an ostensible fair deposition must instantaneously commit to a single explicit ground rather than resort to the ever variable and expandable "form." 309 Presented with a transcript pullulated by precise form objections, a court can more readily determine the extent to which an objection was truly unnecessary, a punishable attempt to "unduly prolong" an examination. ${ }^{310}$ In effect, precise form objections can help facilitate the regulation of the obstreperous conduct inimical to the Rules' essence and function, a means of mitigating the acrimony seen as characteristic of so many contemporary depositions. ${ }^{311}$ Whether widespread or not, ${ }^{312}$ it is that rancor's curtailment that has been the Rules' secondary goal since discovery's "highwater mark." 313

\section{CONCLUSION}

Objection; relevance.

I don't recall ... .

Objection; asked and answered.

I don't recall ... .

Objection; calls speculation.

I don't know... .

Objection; calls for attorney-client privileged information.

I don't recall.

In response to a seeming flood of frustrating objections, the Rules touching upon the oral deposition have been rejiggered again and again since 1978. Before 1938, objections to a question's form had to be stated during a deposition's course; ${ }^{314}$ later they would also have to be "stated

309 See supra Part III.A.

310 FED. R. CiV. P. 30(d) advisory committee's note to 1993 amendment.

311 See supra notes 2, 6, 9, 13

312 See supra note 13.

313 Marcus, supra note 55, at 748 (so describing the 1970 amendments); see also supra Part II.A

314 Moritz, supra note 14, at 1374. 
concisely in a nonargumentative and nonsuggestive manner." 315 Beyond these intimations, the Rules expressly proscribe no objection. ${ }^{316}$ This language, when construed in light of the purpose of discovery generally and the deposition particularly, has generated a perceptible juridical divide over the apposite content of a form objection. Some treat simple form objections as the Rules' required mode, but others insist on the Rules' preference for precise form objections. With the Rules so sparse, these incompatible decisions are the only guidance available for judges, lawyers, and litigants.

A thorough exegesis of Rules 30(c)(2) and (d) and 32(d)(3) and a fair understanding of the Rules' broader context can, however, can finally put an end to this simmering controversy. Because the precise form objection coheres with the textual and the contextual commands of equity's great heir, ${ }^{317}$ Rules 26, 30, and 32 recommend no other type. To wit, "form" alone will never do once reality has its say. Justice and efficiency, merits twined, ${ }^{318}$ then require something more, precision most of all.

Objection; asked and answered.

I already answered that question ... .

Objection; irrelevant; calls for a legal conclusion, violates

attorney-client privilege.

315 FED. R. Civ. P. 30(c)(2).

316 Some states, however, do. See, e.g., N.J. R. CT. 4:14-3(c).

317 See Subrin, Equity's Conquest, supra note 31, at 922; cf. Sherman L. Cohn, The New Federal Rules of Civil Procedure, 54 GEO. L.J. 1204, 1204 (1966) (commending proposed amendments for moving closer to "the aims of a liberal, nontechnical application of the Federal Rules"' (quoting Schlagenhauf v. Holder, 379 U.S. 104, 116, 85 S. Ct. 234, 241, 13 L. Ed. 2d 152, 162 (1964))). By one man's reckoning, "the Federal Rules went beyond equity's flexibility and permissiveness in pleading, joinder, and discovery." Subrin, Equity's Conquest, supra note 31, at 922.

318 See, e.g., Memory Integrity, LLC v. Intel Corp., 308 F.R.D. 656, 659 (D. Or. 2015) (noting that the "touchstone of permissible discovery is embodied in Rule 26(b)(1)" and, at the time, Rule 26(b)(2)(C), the latter's language affixed to Rule 26(b)(1) upon December 1, 2015); Slagowski v. Cent. Wash. Asphalt, 291 F.R.D. 563, 576 (D. Nev. 2013) (quoting Rule 1 and "recognize[ing]that all parties in this action and the court have an interest in the speedy resolution of this action"); Nam v. U.S. Xpress, Inc., No. 1:11-cv-116, 2012 U.S. Dist. LEXIS 189719, at *3, 012 WL 10161528, at *1 (E.D. Tenn. June 25, 20012) (justifying the taking of a much more active role in a case's management "[i]n order to regain control over its own docket, to protect its own resources from waste and abuse by the parties, and to ensure, as much as possible, the "just, speedy, and inexpensive determination' of this case" (quoting FED. R. CIV. P. 1))). Still, as one would expect, "[t]he essentials of justice" must "not be foregone for the sake of expediency." Bethlehem Steel Co. v. NLRB, 120 F.2d 641, 661 (D.C. Cir. 1941) (Stephens, J., dissenting); cf. Van Skiver v. United States, 952 F.2d 1241, 1244 (10th Cir. 1991) (characterizing Rule 60(b)(6) as "grand reservoir of equitable power to do justice in a particular case"). 
2016] A Defense of (Some) Form Objections under the FRCP

Answer the question.

Ijust wasn't sure. 